\title{
High-ozone layers in the middle and upper troposphere above Central Europe: potential import from the stratosphere along the subtropical jet stream
}

\author{
T. Trickl ${ }^{1}$, N. Bärtsch-Ritter ${ }^{2}$, H. Eisele ${ }^{1}$, M. Furger ${ }^{2}$, R. Mücke ${ }^{1}$, M. Sprenger ${ }^{3}$, and A. Stohl ${ }^{4}{ }^{*}$ \\ ${ }^{1}$ Karlsruher Institut für Technologie, Institut für Meteorologie und Klimaforschung (IMK-IFU), Kreuzeckbahnstr. 19, 82467 \\ Garmisch-Partenkirchen, Germany \\ ${ }^{2}$ Paul Scherrer Institut, Labor für Atmosphärenchemie, 5232 Villigen PSI, Switzerland \\ ${ }^{3}$ Eidgenössische Technische Hochschule (ETH) Zürich, Institut für Atmosphäre und Klima, Universitätsstr. 16, 8092 Zürich, \\ Switzerland \\ ${ }^{4}$ Lehrstuhl für Ökoklimatologie, Technische Universität München, Am Hochanger 13, 85354 Freising-Weihenstephan, \\ Germany \\ *now at: Norwegian Institute for Air Research, P.O. Box 100, Instituttveien 18, 2027 Kjeller, Norway
}

Received: 28 July 2010 - Published in Atmos. Chem. Phys. Discuss.: 15 December 2010

Revised: 14 July 2011 - Accepted: 30 August 2011 - Published: 9 September 2011

\begin{abstract}
Specific very dry high-ozone layers, starting roughly two days after the onset of high-pressure periods during the warm season, have been reproducibly observed in the middle and upper troposphere with the ozone lidar in Garmisch-Partenkirchen (Germany). These episodes, previously not understood, were recently analysed based on extending backward simulations with the FLEXPART particle dispersion model to as many as twenty days and on jet-stream analyses including calculations with the LAGRANTO transport model. In all six cases analysed the model results indicate ozone import from the stratosphere on an extremely long path along the subtropical jet stream over the Pacific Ocean, Asia and, in part, all the way back to the Atlantic Ocean. The analysis suggests that stratospheric influence is the most important factor for the increase in ozone and is related to rather shallow transfer of air from the stratosphere into the upper- and mid-tropospheric air streams observed with the lidar. Contributions from the boundary layers of East Asia and North America are just occasionally present, in one case documented by a very dense aerosol plume from the Asian deserts. The considerable vertical and temporal extent of many of these layers and peak ozone mixing ratios between 80 and $150 \mathrm{ppb}$ suggest that the observations are related to an
\end{abstract}

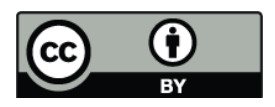

Correspondence to: $\mathrm{T}$. Trickl (thomas.trickl@kit.edu) important mechanism for stratosphere-to-troposphere transport (STT) and also confirm the model predictions of pronounced and persistent STT along the subtropical jet stream.

\section{Introduction}

Very dry air masses with peak ozone mixing ratios of 80 to $150 \mathrm{ppb}$ were consistently detected in all six ozone lidar measurement series covering at least four days carried out in Garmisch-Partenkirchen (Germany) during high-pressure periods between 1996 and 2001 (May to August). These specific high-ozone phases typically started two days after the beginning of the respective high-pressure period and, in part, lasted for several days, which indicates an important contribution to the free-tropospheric ozone budget. These observations were not understood at all since they could be neither interpreted by high ozone from the lower troposphere over North America nor by stratospheric air rapidly subsiding over North America or the Atlantic Ocean (Trickl et al., 2003). Two of these layers contained aerosols indicating the presence of some air from a remote planetary boundary layer (PBL), most likely mixed into these ozone-rich air streams in the vicinity of frontal systems. A common feature is a coherent bundle in the ensemble of backward trajectories initiated in these layers that stays in the middle and upper troposphere between the Pacific Ocean and

Published by Copernicus Publications on behalf of the European Geosciences Union. 
Garmisch-Partenkirchen. However, these trajectories had never been followed back beyond a few degrees west of North America.

Observations of similar very dry air streams with elevated ozone were reported, e.g., by Prados et al. (1999), Bithell et al. (2000), Law et al. (2001) (see also Penkett et al., 2004) and were also found by us in numerous vertical profiles for North America extracted from the MOZAIC (Measurements of Ozone by Airbus In-Service Aircraft, Marenco et al., 1998) data base. In some cases, elevated CO has been found and upper-tropospheric advection from the Pacific is indicated. Newell et al. (1999), by analysing MOZAIC vertical profiles, found that atmospheric layers are most frequently associated with an increase in ozone and a simultaneous decrease in water vapour. Typical altitudes are $6 \mathrm{~km}$ and the average thickness of layers showing this kind of anticorrelation is of the order of $1 \mathrm{~km}$.

The occurrence of high ozone values in the dry layers seen in our results could suggest the presence of a stratospheric component. But, obviously, the mechanism of stratospheric import leading to such high ozone values in such wide layers must differ from the deep intrusions most commonly observed at our observational site (e.g., Reiter et al., 1971; Eisele et al., 1999; Stohl and Trickl, 1999; Trickl et al., 2003, 2010; Zanis et al., 2003). These deep intrusions are mostly confined to narrow air tongues with decreasing ozone mixing ratios as the layers approach the ground. The typical ozone mixing ratios measured in stratospheric streamers at the nearby Zugspitze summit ( $2962 \mathrm{~m}$ a.s.l.) range just between 60 and $80 \mathrm{ppb}$. There is no way to explain the high mid- and upper-tropospheric ozone concentrations in a layer several kilometres thick by an admixture of such a diluted air mass.

Potential source regions are the atmosphere above the Pacific Ocean and East Asia where frequent and pronounced stratospheric air intrusions may occur (Austin and Midgley, 1994; James et al., 2003; Sprenger et al., 2003). Cooper et al. (2005) report on two strong intrusions in 2004 that reached Hawaii and led to the observation of 81 and $115 \mathrm{ppb}$ ozone at the Mauna Loa Observatory ( $3400 \mathrm{~m}$ a.s.1.), respectively. The second event (10 March 2004) even reached the sea level, $60 \mathrm{ppb}$ were recorded at Honolulu. This is particularly remarkable since, at least over Europe, stratospheric intrusions rarely proceed to the ground (e.g., Reiter et al., 1987; Davis and Schuepbach, 1994; Elbern et al., 1997; Eisele et al., 1999; Schuepbach et al., 1999).

Cooper et al. (2004b) also describe that air from a dry intrusion may be mixed into the ascending air streams of adjacent warm conveyor belts (WCBs). In their case study (10 to 11 May 2002) they find that roughly half of the stratospheric component of the dry air stream was dispersed into the upwind and downwind WCBs over the Pacific Ocean. The stratospheric air mass was then lifted back to the upper troposphere and lower stratosphere where it passed over North America and the Atlantic at relatively constant alti- tude. However, trans-Pacific transport may also occur almost entirely in the upper troposphere. Very rapid trans-Pacific transport of radon-rich air (half life 3.8 days) in the upper troposphere was reported on by Kritz et al. (1990) for a number of measurements during summer months. Liang et al. (2007) observed a case in which subsequent trans-Pacific and transNorth-American transport of an ozone-rich air mass took place exclusively at high altitudes (2 August 2004). The entire passage from the West Pacific to the North American east coast occurred within about eight days. A significant ozone enhancement in the upper troposphere above midlatitude North America due to import from the stratosphere was concluded by Cooper et al. (2006).

The almost zonal propagation of air masses to the east at high altitudes described by Cooper et al. $(2004 \mathrm{a}, \mathrm{b})$ and Liang et al. (2007) is similar to what we found for our observations by trajectory analyses. A very intriguing idea for explaining the high ozone values in the dry air streams observed above Garmisch-Partenkirchen would be that of shallow intrusions directly injecting ozone into an uppertropospheric air stream over the Pacific Ocean or farther to the west. Sprenger et al. (2003) locate a maximum in occurrence of shallow intrusions (partly exceeding a relative frequency of $30 \%$ ) between North Africa and the Pacific Ocean between $30^{\circ}$ and $40^{\circ} \mathrm{N}$. This transfer seems to occur in the vicinity of the subtropical jet stream which is a rather persistent feature along this path, weakening in summer (Koch et al., 2006; see also Chen, 1995; Dunkerton, 1995, who emphasize the role of the monsoon circulation for stratospheretroposphere exchange). In fact, Langford et al. (1998) and Langford (1999), examining 5.5 years of lidar data of the Fritz-Peak station (Colorado, USA), suggested that ozone enhancements observed between 6 and $12 \mathrm{~km}$ above this site are correlated with stratosphere-to-troposphere transport (STT) associated with the subtropical jet stream. However, there is limited direct observational material on the processes involved (e.g., Gouget et al., 1996; Cammas et al., 1998; Zachariasse, 2000; Zahn et al., 2002) and the importance of the subtropical jet stream for the overall STT budget had long been ignored (e.g., Gouget et al., 1996). Zachariasse et al. (2000) hypothesize shear-induced differential advection or clear-air turbulence to be responsible for the STT events causing mid-tropospheric maxima in their sonde profiles rather than tropopause folding.

The idea of potential inflow of stratospheric air from the region of shallow intrusions described by Sprenger et al. (2003) as a source of the enhanced ozone, indeed, soon became a strong motivation for the study presented here. A particular challenge has been the enormously long travel of these air masses. For the analysis, carried out within the German ATMOFAST (Atmospheric Long-range Transport and its Impact on the Trace-gas Concentrations over Central Europe; ATMOFAST, 2005; see also AFO 2000) project, backward modelling had to be extended to twenty days in order to clarify the most likely transport pathway. 
Although such a stratospheric component could be identified, some of the elevated ozone could also be related to air pollution export from East Asia. The subtropical Western Pacific is one of the two most important inflow regions for WCBs in the Northern Hemisphere (Stohl, 2001). Cooper et al. (2004a, b) emphasize the role of WCBs in transporting Asian air pollution across the Pacific. As mentioned above they found that these air streams may merge with stratospheric air (see also Liang et al., 2007). As the lofted layers enter North America they stay in the middle and upper troposphere and are rapidly transported to the Atlantic.

In our study we have investigated the potential importance of the stratospheric and Asian components for the six cases mentioned at the beginning of this section. Here, we present the analysis of just three of these cases mentioned, which represent different behaviour: exclusively stratospheric influence (accompanied by a separate layer also containing some North American air, Case 1, Sect. 3.1), a mixed contribution from the stratosphere and the Asian PBL (Case 2, Sect. 3.2), and a situation where two layers with both possibilities coexisted (Case 5, Sect. 3.3). The layers with Asian contributions also include air from the North American PBL. The analysis is now extended to localizing the jet-stream positions and visualizing the trans-tropopause transport in their vicinity.

\section{Methods}

\subsection{Measurements}

In this study we use data from measurements with two lidar systems at IMK-IFU ( $47^{\circ} 28^{\prime} 37^{\prime \prime} \mathrm{N}, 11^{\circ} 3^{\prime} 52^{\prime \prime} \mathrm{E}, 730 \mathrm{~m}$ a.s.l.). The tropospheric ozone lidar (740 ma.s.1.) was completed in its first version in 1990 (Kempfer et al., 1994) and upgraded in 1994 and 1995 (Eisele and Trickl, 1997, 2005). It has a unique vertical range between $0.2 \mathrm{~km}$ and roughly $15 \mathrm{~km}$ above the ground, features low uncertainties of about $\pm 3 \mathrm{ppb}$ below $4 \mathrm{~km}$ and $\pm 6 \mathrm{ppb}$ (under optimum conditions) in the upper troposphere. The upper-tropospheric performance may be degraded in the presence of high lowertropospheric ozone absorbing a lot of the ultraviolet laser emission and by enhanced sky light in summer, in particular in the presence of clouds. The vertical resolution is dynamically varied between $50 \mathrm{~m}$ and a few hundred metres, depending on the signal-to-noise ratio that decreases with altitude. The lidar has been used in numerous investigations focussing on atmospheric transport (e.g., Eisele et al., 1999; Stohl and Trickl, 1999; Seibert et al., 2000; Carnuth et al., 2002; Roelofs et al., 2003; Trickl et al., 2003, 2010; Zanis et al., 2003).

Aerosol backscatter coefficients were taken from the 313nm channel of the ozone lidar or from measurements with the big aerosol lidar at IMK-IFU (730 m a.s.1.), a primary instrument of the Network of the Detection of Atmospheric
Composition Change (NDACC, http://www.ndsc.ncep.noaa. gov/). This system was originally built in 1973, based on a ruby laser, and has been continually used for measurements of stratospheric aerosol since 1976 (e.g., Jäger, 2005; Deshler et al., 2006; Fromm et al., 2008, 2010). The lidar was converted to a spatially scanning system in the early $1990 \mathrm{~s}$ for additional investigation of contrails (Freudenthaler et al., $1994,1995)$ and, for the routine measurements, has been operated at the wavelength of $532 \mathrm{~nm}$ ever since. The measurements discussed here were either routine early-night stratospheric measurements (vertical pointing, range: $2 \mathrm{~km}$ a.s.l. to more than $40 \mathrm{~km}$ a.s.1.) or campaign measurements (May 1999, at elevation angles mostly of 25 to 45 degrees in order to improve the coverage of the PBL). For an optimum signal-to-noise ratio in the upper troposphere we evaluated only measurements for the highest angles. With this system small aerosol structures exceeding roughly $2 \%$ of the Rayleigh return at $532 \mathrm{~nm}$ (that corresponds to a visual range of more than $400 \mathrm{~km}$ above $3 \mathrm{~km}$ ) can be resolved within the free troposphere. The aerosol backscatter coefficients can be calculated with a relative uncertainty of 10 to $20 \%$.

In addition, in-situ ozone data from the monitoring stations Garmisch-Partenkirchen (745 ma.s.1., at IMK-IFU), Wank (1780 m a.s.1.) and Zugspitze (2962 m a.s.l.) have been used for comparison (information on some of the instrumentation is given by Trickl et al., 2010). These stations are located at distances of about $8 \mathrm{~km}$ from the lidar.

In May 1999, a radiosounding system was operated at Krün $\left(47^{\circ} 30^{\prime} 38^{\prime \prime} \mathrm{N}, 11^{\circ} 16^{\prime} 52^{\prime \prime} \mathrm{E}, 876 \mathrm{~m}\right.$ a.s.1.), $17 \mathrm{~km}$ roughly to the east of IMK-IFU, by a team of the PaulScherrer Institute (PSI, Switzerland) as a contribution to the VOTALP "Munich" field campaign (VOTALP II, 2000). For the study presented here this system yielded important complementary information for the lidar and station measurements in the Garmisch-Partenkichen area. A VIZ W-9000 LORAN-C radiosonde was used (http://www.sippican.com). Each sounding provided the standard meteorological parameters pressure, temperature, relative humidity, and horizontal wind vector as a function of altitude. Relative humidity was measured with a fast-response carbon hygristor. Ten of the sondes were equipped with an additional ozone sensor (ENSCI Corporation, model Z ECC). Sonde measurements were performed from 26 to 28 May 1999, with a total of 16 ascents in irregular intervals during daylight hours.

As in the preceding publications (Stohl and Trickl, 1999; Trickl et al., 2003) we use ozone and water-vapour data from the MOZAIC (Measurements of Ozone and Water Vapor by Airbus In-Service Aircraft) project (Marenco et al., 1998) that have been routinely made onboard five commercial airliners, again for the May 1996 case (Case 1, see below). This dataset provides daily vertical profiles over Europe, transects at cruising altitude over the North Atlantic and occasional vertical profiles at various locations over North America. 


\subsection{Models}

The transport pathways and source regions were identified by calculations with the FLEXTRA trajectory model (Stohl et al., 1995; Stohl and Seibert, 1998) and the FLEXPART particle dispersion model (Stohl et al., 1998, 2005; Stohl and Thomson, 1999). Both models were driven with operational analyses from the European Centre for Medium-Range Weather Forecasts $(\mathrm{ECMWF})$ with $1^{\circ} \times 1^{\circ}$ resolution. Analyses at 00:00, 06:00, 12:00 and 18:00 UTC and 3-h forecasts at intermediate times (03:00, 09:00, 15:00, 21:00 UTC) were used.

In this study, ten-day backward trajectories were taken as the primary tool for visualizing (within this limited time period) the altitude of confined air streams that stay in the middle and upper troposphere. The advantage of FLEXTRA trajectory calculations is that certain properties (such as position, potential vorticity and potential temperature) can be tracked unambiguously as a function of time. However, trajectory analyses are problematic for the investigation of very long transport pathways due to the neglect of dispersion as a result of turbulence and convection, and due to a decreasing horizontal density (coverage) as one goes backward in time. Therefore, backward calculations with the FLEXPART model as described in previous studies (e.g., Stohl et al., 2003; Trickl et al., 2003; Huntrieser et al., 2005) have become the principal analysis tool.

FLEXPART calculates the trajectories of a multitude of particles using the mean winds interpolated from the meteorological input fields plus random motions representing turbulence. For moist convective transport, the scheme of Emanuel and Živković-Rothman (1999), as described and tested by Forster et al. (2007), is used. FLEXPART was run either fifteen or twenty days backward in time to produce information on the emission sources potentially contributing to ozone formation in the sampled air masses. Backward simulations are normally released from 250 -m boxes stacked vertically, here all the way up to $12 \mathrm{~km}$ along the lidar profile, with 40000 particles released per box.

The primary output of these so-called retroplume calculations is the emission sensitivity, as described by Seibert and Frank (2004) and Stohl et al. (2003), which describes the pathway of the sampled air mass. The value of the emission sensitivity (in units of $\mathrm{sg}^{-1}$ ) in a particular grid cell is proportional to the particle residence time in that cell. It is a measure for the simulated mixing ratio at the receptor that a source of unit strength $\left(1 \mathrm{~kg} \mathrm{~s}^{-1}\right)$ in the respective grid cell would produce. Integrating the emission sensitivity over the entire atmospheric column is an effective way of displaying the overall horizontal transport pathway of a sampled air mass. Showing the emission sensitivity for a certain altitude level (e.g., $12 \mathrm{~km}$ ), illustrates the pathway at this altitude level. The emission sensitivity in the lowest layer (so-called footprint) can also be folded (i.e., multiplied) with the distribution of the emission flux densities (in units of $\mathrm{kg} \mathrm{m}^{-2} \mathrm{~s}^{-1}$ ) from a suitable emission inventory to yield a so-called source-contribution map representing the geographical distribution of sources contributing to the simulated mixing ratio at the receptor. Spatial integration of the source contributions finally gives the simulated mass mixing ratio in the tracked air mass box at the lidar location. By combining simulations for all altitudes, vertical profiles of tracer mixing ratios, split into contributions from different continents, can be displayed. The emissions were taken from the EDGAR 3.2 inventory for the year 1995 or 2000 (Olivier and Berdowski, 2001). For the latest simulations, covering twenty backward days (see below), the regional inventory of Frost et al. (2006) was used for North American emissions. The emission sensitivities are calculated for a passive tracer, i.e., loss processes are not included in the simulations. Thus, source contributions quantify the total emissions that have entered the sampled air mass during the tracking period. For the analyses presented in this paper we mostly select $\mathrm{CO}$ and $\mathrm{SO}_{2}$ as emission tracers, $\mathrm{SO}_{2}$ being indicative of contributions from China due to the strong coal burning.

Particle positions are clustered as described by (Stohl et al., 2002) to provide summary information on the altitude and position of the retroplumes clusters as a function of time. Five clusters are determined every $24 \mathrm{~h}$. Clusters can separate, but also merge on other days. In retroplume cluster plots, the mean positions of the individual clusters (cluster centroids) are marked by a circle with a radius proportional to the number of particles in the respective cluster. In additional horizontal maps (used, but not explicitly shown here), the colour of these circles represents their mean single-day altitude and a number gives the backward time in days.

FLEXPART simulations for this study were done at different times over a period of several years and, therefore, not all products were available for all cases presented here, or the model set-up deviated slightly from what is described above. We first carried out fifteen-day that comprised a valuable special feature not available in the later analyses: They highlight the areas where an altitude of $12 \mathrm{~km}$ was reached or crossed, i.e., where stratosphere-to-troposphere transport (STT) might have occurred. $12 \mathrm{~km}$ is a typical mid-latitude tropopause height in summer, but is not representative of the tropopause at lower latitudes. The fifteen-day simulations differ from the later ones also in the particle release just from a single larger time-altitude box. Recently, twenty-day calculations were added in order to harden the findings for fifteen days and to benefit from the full set of analysis products meanwhile available. Most importantly, the twenty-day calculations yield altitude information for the different quantities, such as the stratospheric fractions and the emissions advected from the different continents. The threshold condition for the stratospheric fractions is chosen as 2 pvu (potential vorticity units) polewards from 30 . The thermal tropopause is applied in the tropics.

The role of the jet streams and the vertical exchange between the stratosphere and the troposphere (STE) is 
elucidated with additional calculations with the Lagrangian Analysis Tool (LAGRANTO; Wernli and Davies, 1997a, b). For five of the six cases (those discussed by Trickl et al., 2009), these calculations highlight regions along the jet streams where, indeed, STT occurred. The calculations are based on the ERA-40 re-analysis data set of ECMWF forecasts in the entire Northern Hemisphere and identify STT and TST (troposphere-to-stratosphere transport) according to the methods presented by Wernli and Bourqui (2002), Sprenger et al. (2003) and Sprenger and Wernli (2003). Roughly $7 \times 10^{5}$ trajectory parcels per day were released in the troposphere and stratosphere, each representing a box of initially $80 \mathrm{~km} \times 80 \mathrm{~km} \times 30 \mathrm{mbar}$. Whenever a trajectory crosses the 2-pvu tropopause the latitude, longitude, time and pressure at the crossing are saved. Furthermore, transient crossings are excluded by invoking a residence-time criterion: the trajectories must be within the stratosphere for $48 \mathrm{~h}$ prior and within the troposphere $48 \mathrm{~h}$ after the crossing for STT, and vice versa for TST. In the figures, the wind speed at $200 \mathrm{mbar}$ is shown and all STT and TST events within a vertical range from 250 to 150 mbar are marked.

\section{Results}

All six cases mentioned in the introduction were analysed in detail. An overview is given in Table 1. As further explained in Sect. 3.1 the lidar observations were made under similar meteorological conditions, i.e., starting with the clearing at the end of a trough period and extending several days into a high-pressure period. A similar principal layer structure has been found during the first two days, related to the impact of three different kinds of long-range transport (Sects. 3.1 and 3.3 of Trickl et al., 2003). After roughly two days consistently additional mid- and upper-tropospheric high-ozone import from beyond America was registered, which is the topic of this paper.

For the input from regions west of North America three principal sources have been identified, STT along the subtropical jet stream, STT over the North-West Pacific and uplifting of air masses from the Asian PBL. Three of the six cases have been selected for illustration (1,2 and 5) and are discussed following the same sequence, a brief introduction on general aspects of the period and on what is already known from earlier work, a description of the observational data, backward modelling to clarify the importance of stratospheric and PBL components, and a visualization of the jetstream positions and STT in their vicinity.

Due to the large amount of material derived from the analysis some of the figures were moved to the electronic Supplement. Information sources on the cases not discussed here are given in the footnotes to Table 1.

\subsection{Case 1: 31 May 1996}

\subsubsection{Background}

The measurements with the ozone lidar in GarmischPartenkirchen during a short high-pressure period between 29 May and 1 June 1996, have been intensively discussed previously(a figure of the time series is, therefore, only given in the electronic Supplement, Fig. $S_{1}$ ). They were carried out to study a predicted stratospheric air intrusion (Eisele et al., 1999) that has subsequently been the subject of several modelling efforts including model validation and intercomparison (Feldmann et al., 1999; Stohl et al., 2000; Cristofanelli, 2003; Meloen et al., 2003). This time series yielded the first evidence of significant trans-Atlantic transport of ozone (Stohl and Trickl, 1999 (remark in Sect. 5); Trickl et al., 2003).

The temporal development of the vertical distribution of ozone is, at most altitudes, related to an anti-cyclonic advection pathway around the northern part of a high-pressure zone during its early phase, and a somewhat straighter arrival from westerly directions at some altitudes when the highpressure zone moves farther to the east (Trickl et al., 2003). The arrival path of the deep stratospheric air intrusion observed at the beginning differs since its source region is located between Greenland and Norway (Stohl et al., 2000). As a consequence of three different principal contributing source regions a descending three-layer structure is seen within the free troposphere, with the stratospheric air at the bottom and two layers of PBL air above the intrusion. This is a general behaviour found for all the cases of this study and was also observed in several more, less comprehensive lidar measurement series at Garmisch-Partenkirchen under similar meteorological conditions.

The first layer above the intrusion is related to anticyclonic low-ozone import from the subtropical Atlantic. High-ozone layers of trans-Atlantic origin were observed above $4 \mathrm{~km}$ almost during the entire period. The North American ozone contributions were concentrated mostly above $8 \mathrm{~km}$ until the end of the observations and also in a separate layer that gradually descended to $4 \mathrm{~km}$ and disappeared during the first hours of 31 May. The most important source regions were Texas, Mexico and, to some extent, also the south-western United States (US). Some uncertainty exists concerning the impact of a large convective cell in the frontal system lifting the air masses to the mid-troposphere. Most importantly, significant stratospheric air inflow into the troposphere could be excluded over North America and the Atlantic.

\subsubsection{Observations}

The high-ozone layer of interest in this study passed over Garmisch-Partenkirchen on 31 May between 4.3 and $7 \mathrm{~km}$ (towards the end: $8 \mathrm{~km}$. It could not be analysed by Trickl 
Table 1. Overview of the high-ozone layers analysed.

\begin{tabular}{lrrrrcc}
\hline Case & Start Date & Duration & Typ. Vert. Range & $\mathrm{O}_{3}$ Mix. Ratio & Asian Influence & Aerosol \\
\hline 1 & 31 May 1996 & $\geq 21 \mathrm{~h}$ & $4.3-7.5 \mathrm{~km}$ & $80-100 \mathrm{ppb}$ & no & no \\
& unknown & $7.5-11 \mathrm{~km}$ & $80 \mathrm{ppb}$ & no & low \\
2 & 26 May 1999 & $>4 \mathrm{~d}$ & $4.5-9 \mathrm{~km}$ & $80-150 \mathrm{ppb}$ & yes & strong \\
3 & 9 September 2000 & $>15 \mathrm{~h}$ & $7-10 \mathrm{~km}$ & $80-110 \mathrm{ppb}$ & no & no \\
4 & 23 June 2001 & $\geq 2 \mathrm{~d}$ & $5.5-12 \mathrm{~km}$ & $70-110 \mathrm{ppb}$ & no & no \\
5 & 22 July 2001 & $1.5 \mathrm{~d}$ & $5.5-8 \mathrm{~km}$ & $70-90 \mathrm{ppb}$ & low & no \\
& & $>0.5 \mathrm{~d}$ & $8-10 \mathrm{~km}$ & $100-120 \mathrm{ppb}$ & low & no \\
6 & 13 August 2001 & $>3 \mathrm{~d}$ & $6-11 \mathrm{~km}$ & $100-140 \mathrm{ppb}$ & no & no \\
\hline
\end{tabular}

${ }^{a}$ Descriptions of more analyses for these cases are given by Trickl et al. (2009). Time series can be found in Trickl et al. (2003, 2010).

b For Case 4 only a single full-size FLEXPART twenty-day backward analysis was made (23 June, 22 CET, Central European Time $($ CET $)=$ UTC $+1 \mathrm{~h})$. This model run confirmed the principal transport pattern found for the other cases. Additional trajectory calculations ensured that the air masses arrived from the Pacific Ocean for the entire period specified in Table 1.

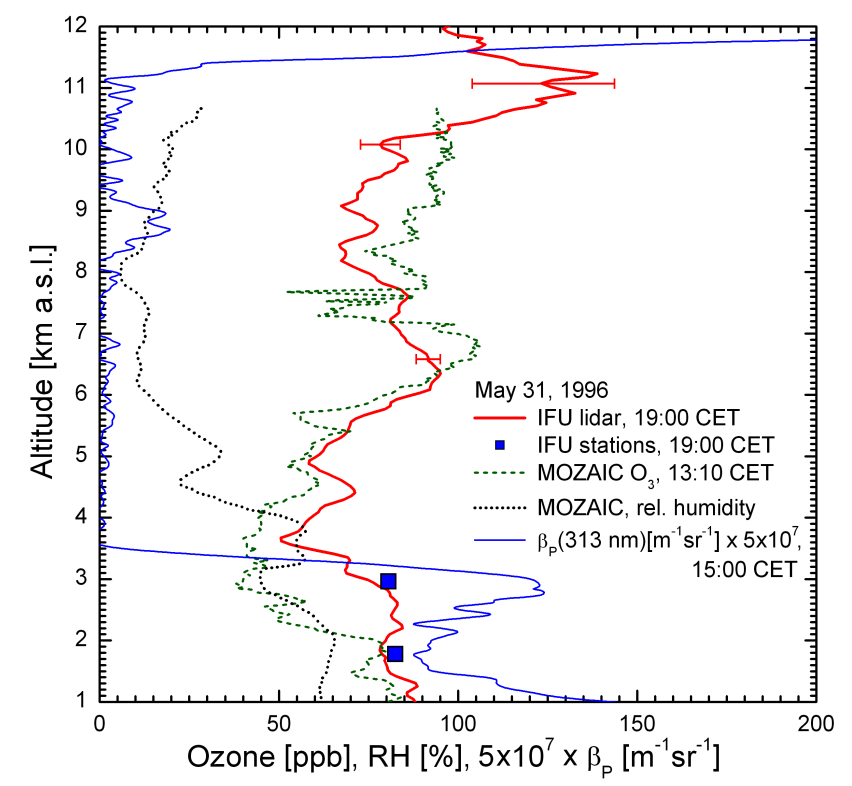

Fig. 1. Ozone mixing ratio and 313-nm aerosol backscatter coefficient $\beta_{P}$ above IMK-IFU (Garmisch-Partenkirchen) and MOZAIC ozone and relative-humidity $(\mathrm{RH})$ profiles for the departure of a MOZAIC aeroplane rom Frankfurt (Germany); see Fig. 12 in (Trickl et al., 2003). The ozone mixing ratios for the nearby summit stations Wank (1780 m a.s.l.) and Zugspitze (2962 m) are also given for comparision. The ozone peak at $11 \mathrm{~km}$ is a temporary feature and somewhat uncertain due to the presence of cirrus clouds just below the tropopause ( $13.4 \mathrm{~km} \pm 0.2 \mathrm{~km}$ during 31 May). The times are given in Central European Time $(\mathrm{CET}=\mathrm{UTC}+1 \mathrm{~h})$.

et al. (2003) due to the insufficient model domain covering just North America and the Atlantic. These model simulations showed some ongoing North American influence in the upper troposphere (see above), but, on 31 May, they did not yield any evidence of a significant PBL contribution in this layer during a major part of the day. An example of an ozone profile from this period, measured at 19:00 CET (Cen- tral European Time $=\mathrm{UTC}+1 \mathrm{~h}$ ), is shown in Fig. 1 together with a MOZAIC ozone and a humidity profile for Frankfurt several hours earlier (same MOZAIC profiles as in the preceding publication). These two measurements show the best mutual agreement on that afternoon, which reflects the fact that Garmisch-Partenkirchen was approximately downwind of Frankfurt (distance: roughly $330 \mathrm{~km}$ ) and the ascent route of the MOZAIC Airbus towards the Netherlands. The air mass was very dry (just 5 to $8 \%$ for the Munich radiosonde, launched $100 \mathrm{~km}$ north of the lidar site) indicating that a potential stratospheric air component from beyond North America could have created the high ozone values. The considerable width of the layer suggested a potentially strong contribution to STT and, thus, motivated an extension of the analysis. In addition, the presence of a polluted Asian air mass was considered.

The backscatter profiles for $313 \mathrm{~nm}$ ("off" wavelength of the ozone lidar) reveal the presence of aerosol between 8 and $9.5 \mathrm{~km}$ in the measurements on 31 May, indicating long-range advection from a remote PBL. This structure just slighty exceeds the strong background noise from Rayleigh backscattering at $313 \mathrm{~nm}$. The example with the least noisy base line close to the 19:00-CET ozone measurement is included in Fig. 1. The maximum particle backscatter coefficient, $\beta_{P}$, in that layer $(8.6 \mathrm{~km})$ corresponds to just $7 \%$ of the Rayleigh backscatter coefficient, which, nevertheless, means a significant contribution due to the extreme increase of Rayleigh scattering towards the ultraviolet spectral region. The NDACC measurement with the big aerosol lidar on 31 May was made at about 21:30 CET, i.e., at the end of the period with the highest ozone values (not shown). There was, still, minor aerosol around $8 \mathrm{~km}$, discernible due to the much lower Rayleigh background at $532 \mathrm{~nm}$. During the entire period of interest on 31 May no aerosol is seen in the region between $4 \mathrm{~km}$ and that aerosol peak next to $8 \mathrm{~km}$, in agreement with our earlier conclusion of an absence of a North American component in the region around the $95 \mathrm{ppb}$ ozone hump in Fig. 1. 
May 31, 1996, 7-17 CET, 5-7 km a.s.l.
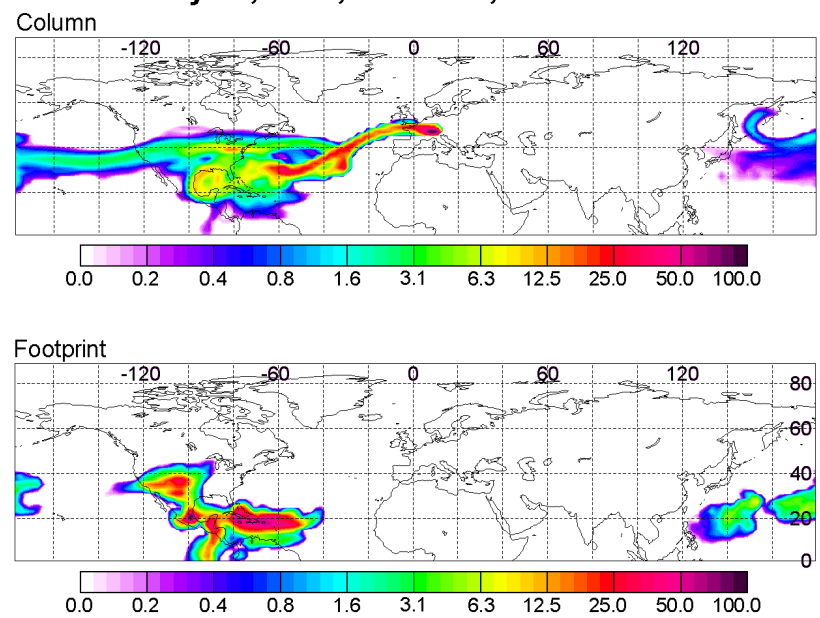

Source Contribution
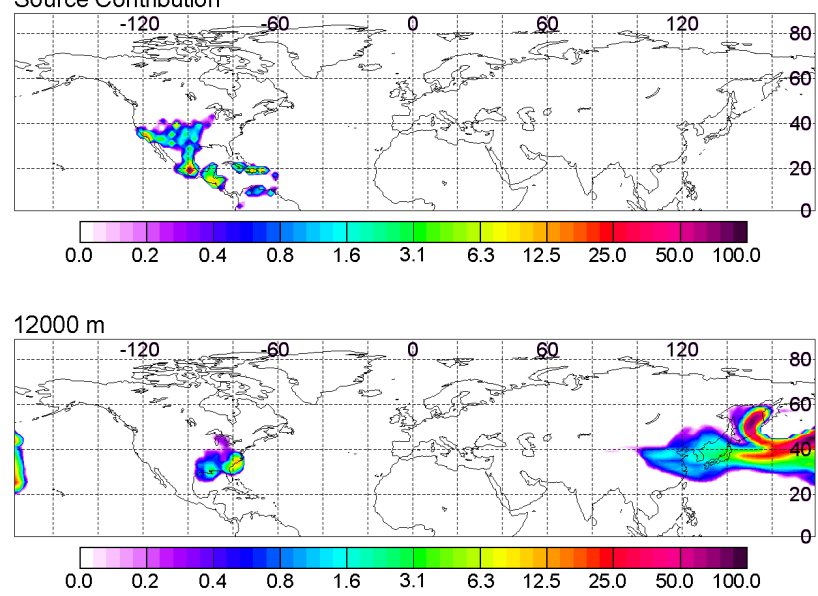

Fig. 2. FLEXPART fifteen-day backward (retroplume) simulation for 31 May 1996, 07:00 to 17:00 CET and 5 to $7 \mathrm{~km}$ a.s.l. above IMK-IFU; the panels show emission sensitivities (see Sect. 2.2). The maximum values of the different scales are uncertain and, therefore, not specified. The PBL source contribution was determined by folding the footprint emission sensitivity (i.e., the emission sensitivity for the lowest layer) with $\mathrm{NO}_{\mathrm{x}}$ emissions from the EDGAR inventory.

\subsubsection{Retroplume analysis (FLEXPART)}

In order to identify the origin of the elevated ozone concentrations on 31 May fifteen-day FLEXPART backward ("retroplume") simulations were carried out for the two altitude ranges of interest above Garmisch-Partenkirchen (5 to $7 \mathrm{~km}$ and 7 to $10 \mathrm{~km}$ a.s.1.) and a major part of that day (see Figs. 2 and 3). The emission sensitivities are shown for the PBL (in the third panel also folded with $\mathrm{NO}_{\mathrm{x}}$ emissions to highlight the source regions) and $12000 \mathrm{~m}$, as well as integrated over the entire column. The $12000-\mathrm{m}$ panel shows that an extension of the upper-tropospheric air flow to the west exists and provides a crude guess of the locations of po-
May 31, 1996, 7-17 CET, 7-10 km a.s.I.
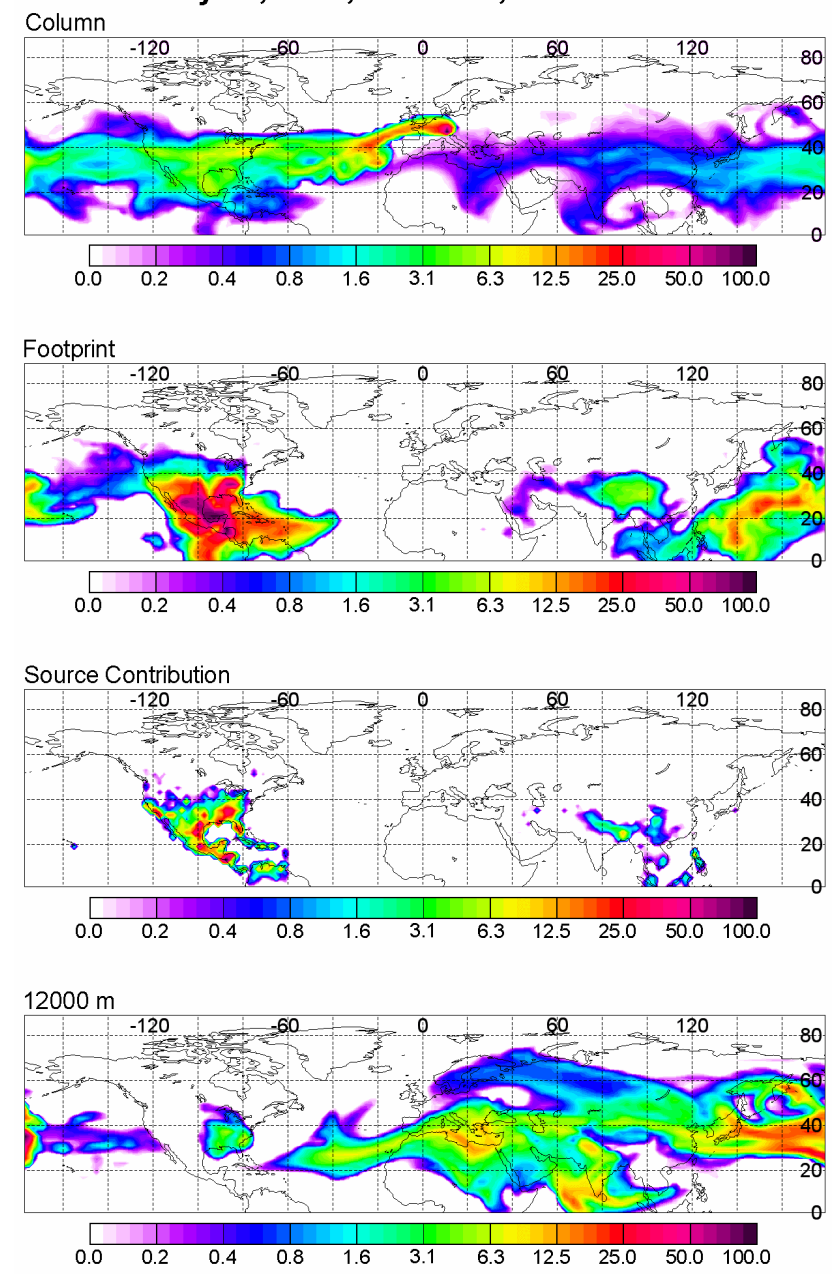

Fig. 3. Same as Fig. 2, but for the altitude range 7 to $10 \mathrm{~km}$ a.s.1. above IMK-IFU.

tential transitions from the stratosphere into the troposphere. The simulation for the altitude range between 5 and $7 \mathrm{~km}$ (Fig. 2) confirms the absence of a significant PBL contribution in this layer. This supports the idea of stratospheric influence on the observed ozone rise. In agreement with our earlier findings no significant stratospheric influence is seen over North America and the Atlantic (Trickl et al., 2003). This could be quite different over the Pacific. The 12000-m panels of both Figs. 2 and 3 show clear sensitivity signatures over the West Pacific between roughly $30^{\circ}$ and $60^{\circ} \mathrm{N}$. Some of the air mass at the higher altitude originates from South Asia, North Africa, and the Atlantic, circumnavigating the globe within fifteen days (Fig. 3). The route overlaps with the streak of maximum "shallow-fold" activity published by Sprenger et al. (2003).

$12 \mathrm{~km}$ does not necessarily represent the tropopause at low latitudes. However, a big intrusion is indicated in Fig. 3 between Kamchatka and about $40^{\circ} \mathrm{N}, 180^{\circ} \mathrm{E}$. The existence of 


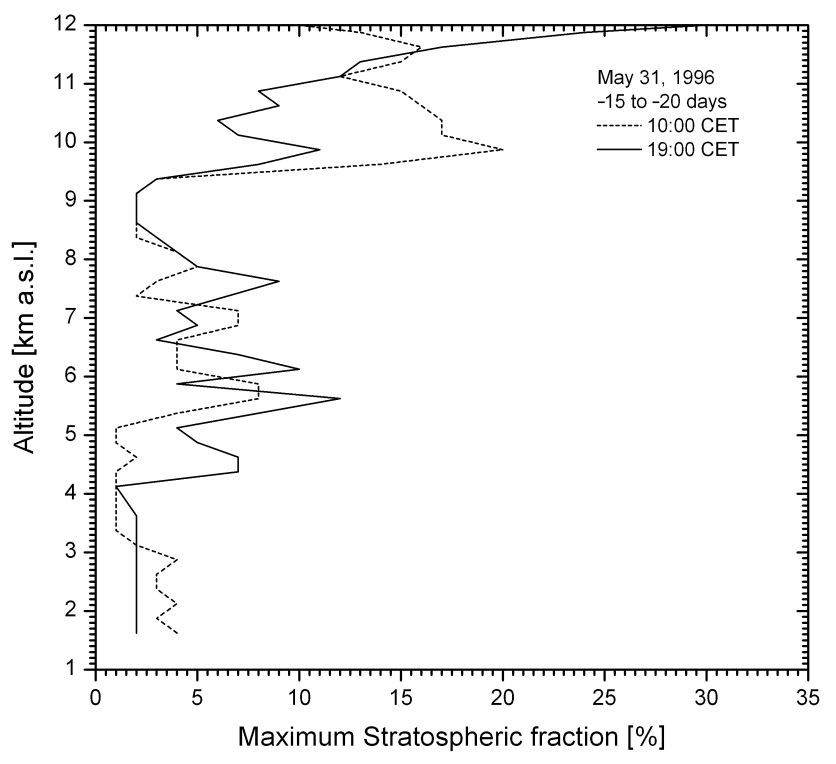

Fig. 4. Vertical distribution of the maximum stratospheric fraction in the twenty-day retroplumes calculated for the four measurements in Fig. 1, extracted from the results for days -20 to -15 , for which, though slightly outside the ozone maximum in Fig. 1, the highest fractions were obtained.

this intrusion was hardened also by forward trajectory calculations initiated over that area between 10 and $12 \mathrm{~km}$ a.s.l. (HYSPLIT model; http://ready.arl.noaa.gov/HYSPLIT.php; Draxler and Hess, 1998). It was found that the trajectories mostly stay above $5 \mathrm{~km}$ and proceed towards North America and, in part, Europe.

The interpretation did not change when we recently extended the FLEXPART simulations to twenty days. The high-altitude cluster for the slower 4.5-7.5-km layer can now be (zonally) followed to a zone around $40^{\circ} \mathrm{N}$, between $40^{\circ} \mathrm{E}$ and $60^{\circ} \mathrm{E}$. The vertical profile of the highest single-day STT fractions for the (most important) earliest days is shown in Fig. 4. For 19:00 CET, there is some obvious positive correlation with the ozone structure in Fig. 1, even that exhibits a wide maximum between 4 and $8 \mathrm{~km}$ capped by a shallow minimum between 8 and $9.5 \mathrm{~km}$, with the ozone values again increasing in the upper troposphere. Figure 5 gives some more details of the analysis for three different altitude bins with different STT fractions, representing the respective layers. The second panel of Fig. 5 shows the result for the bin (5500 to $5750 \mathrm{~m})$ with the highest stratospheric influence in that layer (Fig. 4), found on days -20 to -15 . For the early period the fractions do not vary much, a rather general behaviour for all cases (even over more days, see Sect. 3.2). The vertical distribution of the mean cluster positions shows one component staying at $10 \mathrm{~km}$ and higher for an extended period of time, in contrast to the other two panels corresponding to layers with almost negligible STT. This behaviour supports the idea of shallow STT.
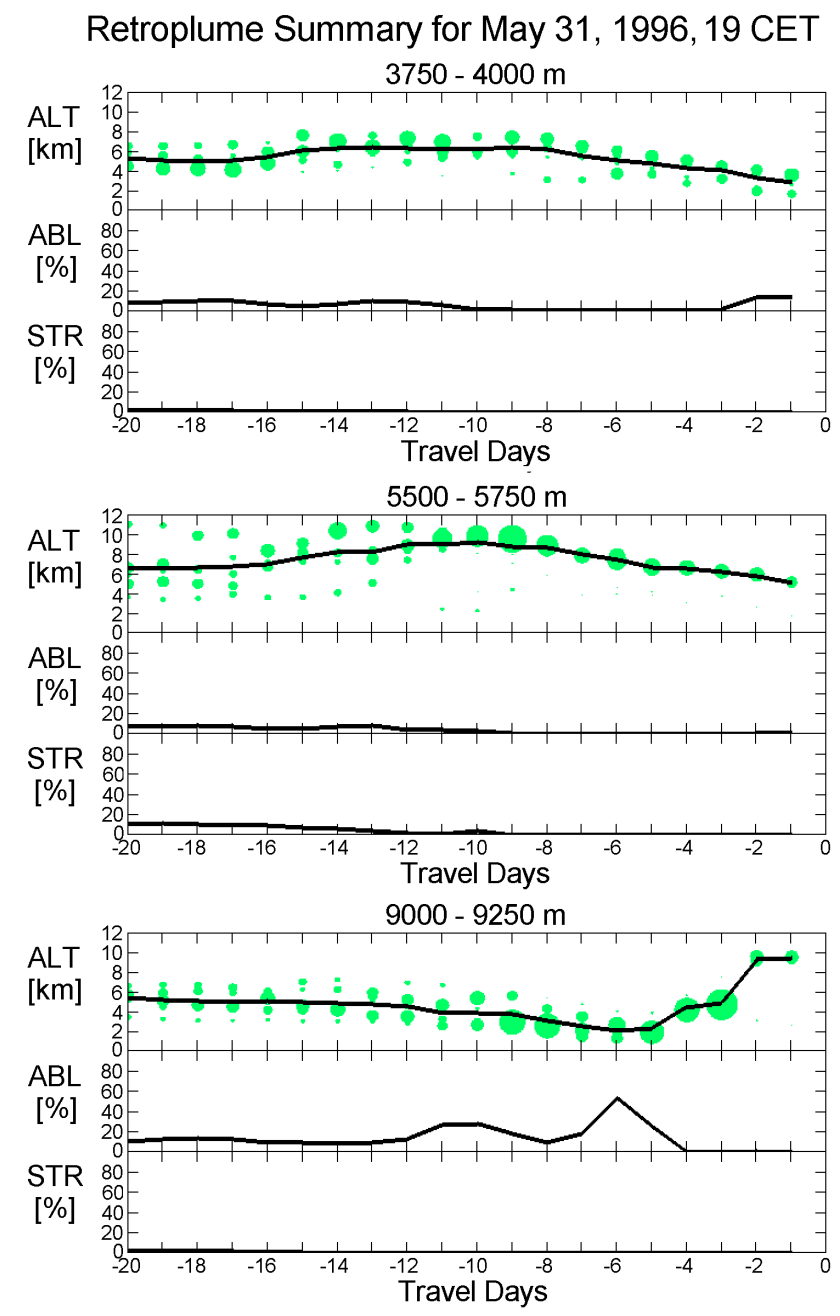

Fig. 5. Retroplume summaries from the twenty-day simulation for three selected altitude ranges above Garmisch-Partenkirchen initiated at the time of the lidar measurement in Fig. 1. The panels show the approximate vertical position (ALT: altitude) of the backward plume during the preceding 20 days and the relative single-day contributions from the PBL (ABL) and the stratosphere (STR). The diameter of the green circles represents the number of particles in a given cluster for the respective days. For more details see Sect. 2.2.

$12 \%$ of stratospheric influence looks moderate, but can be converted into an ozone enhancement by up to $55 \mathrm{ppb}$, assuming ozone values of up to $0.5 \mathrm{ppm}$ within the first few kilometres above the tropopause, as seen in many lidar measurements, and background mixing ratios of the order of $50 \mathrm{ppb}$. It is interesting to note that, at this late time (19:00 CET), there is little influence from the intrusion over Kamchatka, suggesting that, in this example, most of the STT must have taken place along the long lower-latitude branch of the backward plume.

In the upper troposphere (Fig. 3 and lowest panel in Fig. 5) PBL contributions co-existed with stratospheric contributions, except for a short gap with low STT fractions around 


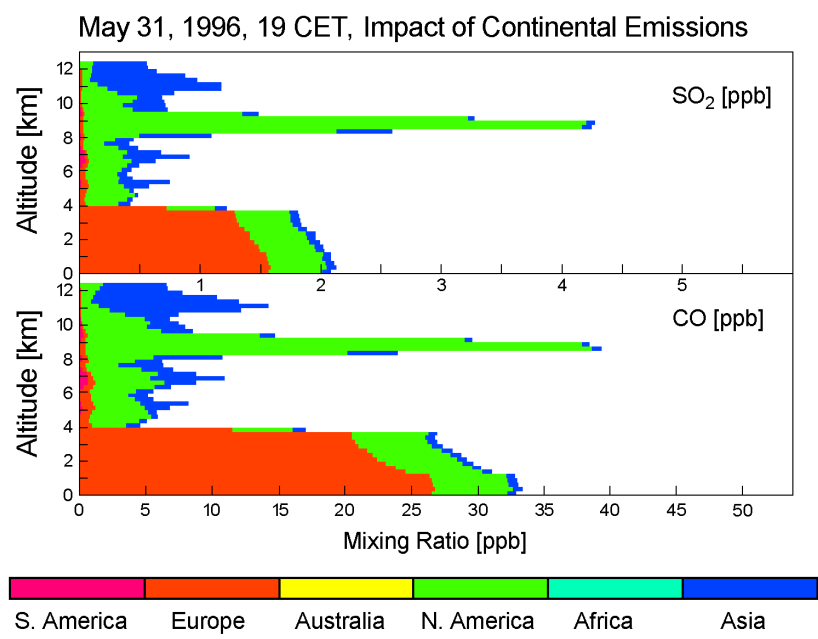

Fig. 6. Vertical distribution of FLEXPART $\mathrm{SO}_{2}$ and $\mathrm{CO}$ emission tracers from the different source continents above GarmischPartenkirchen, simulated for the time of the lidar measurement on 31 May 1996 shown in Fig. 1 (twenty-day simulation). Please, note that the numbers in the mixing-ratio scales are just rounded to the next integer value.

$8.9 \mathrm{~km}$. Pronounced contributions from various polluted regions around the Gulf of Mexico, Mexico City and from Southern California are seen. The local air-quality station network in Mexico City reports peak values between 180 and almost 230 ppb between 12 and 18 May, 125 ppb on 19 May, and between 150 and almost $270 \mathrm{ppb}$ until the end of May (http://www.sma.df.gob.mx/simat/). Again, Asian contributions are almost absent. This can also be seen from the calculated vertical distribution of the emissions from the different continents reaching Garmisch-Partenkirchen shown in Fig. 6. The maximum PBL contribution is located between 8.0 and $9.5 \mathrm{~km}$, exactly where the aerosol peak was found with both lidar systems.

\subsubsection{Jet-stream and Lagrangian STE analysis (LAGRANTO)}

For comparing the FLEXPART results with the positions of the subtropical jet stream additional visualizations of the jet streams in the Northern Hemisphere were derived from the ERA-40 re-analysis, starting about fifteen days before the beginning of the respective high-ozone period. The results were plotted at intervals of six hours. In Fig. 7 we show images for four different times, corresponding to an eastward propagation of the air parcels.

The subtropical jet stream exhibits changes in wind speed. The areas of the highest wind speed are dominated by the eastward component of the zonal wind (not shown). The weaker westward components (e.g., Dunkerton, 1995) are slightly displaced in latitude and cannot be resolved in Fig. 7. The latitudinal oscillations of the jet position are much less pronounced than those of the sub-polar jet stream. The position can, thus, be compared relatively well with the latitudinal position of the "12000-m" section of the FLEXPART backward plume (accurate longitudinal comparisons are impeded by the considerable temporal spread). The agreement is excellent. The jet stream follows the FLEXPART plume to North America, with an obvious northward motion over the Pacific and North America. All along the jet vertical exchange between the stratosphere and the troposphere takes place, confirming the conclusions for the FLEXPART calculations. In particular, the STT dots are found exactly where they would be expected from Fig. 3 almost fifteen days backward in time, e.g., next to the Strait of Gibraltar in the top panel and farther to the east (Caucasus, China, south of Japan) in the following ones. The downward transport marked by the green dots seems to occur preferentially on the north side of the subtropical jet stream, as one would expect from the counter-clockwise rotation of the air-masses around the jet (see Sect. 4). It is interesting to note that sometimes STT and TST (troposphere-to-stratosphere transport) simultaneously occur in the same confined area, which is in some agreement with the idea of shallow exchange. A clear assignment of the locations of STT or TST to the phase of a single high-velocity streak is very difficult. On the day of arrival over Garmisch-Partenkirchen the jet stream is located north of Germany (not shown). Thus, the high-ozone air mass does not approach the observational site inside the jet stream itself as initially thought. However, due to the short transport time once around the globe most of the transport must have taken place not too far away from the locations of the highest velocities.

\subsection{Case 2: 26-30 May 1999}

\subsubsection{Background}

The ozone series between 26 and 30 May 1999, showed the longest persisting high mixing ratios ever observed with the ozone lidar in the middle and upper troposphere above Garmisch-Partenkirchen (Trickl et al., 2003). The ozone mixing ratio above $4 \mathrm{~km}$ reached values between 80 and roughly $150 \mathrm{ppb}$. The analysis showed sources in the North American PBL, but also a strong, almost horizontal highaltitude flow from the Pacific to Europe. On 27 May, 70 to $80 \mathrm{ppb}$ were observed also below $4 \mathrm{~km}$ and ascribed to direct input from the Eastern US, one of the rare cases in which this has led to the observation of a pronounced rise in ozone at the Zugspitze summit (see, Stohl et al., 2003 and Huntrieser et al., 2005 for another example). The $\mathrm{NO}_{\mathrm{y}}$ mixing ratios at the nearby Wank station (1780 m a.s.l.) were just between 1 and 2 ppb which indicates a moderate European contribution to this air mass.

The mobile radio-sounding station, operated by the PSI team at Krün between 26 and 28 May (see Sect. 2.1), yielded similar ozone profiles as the lidar, the only major difference 

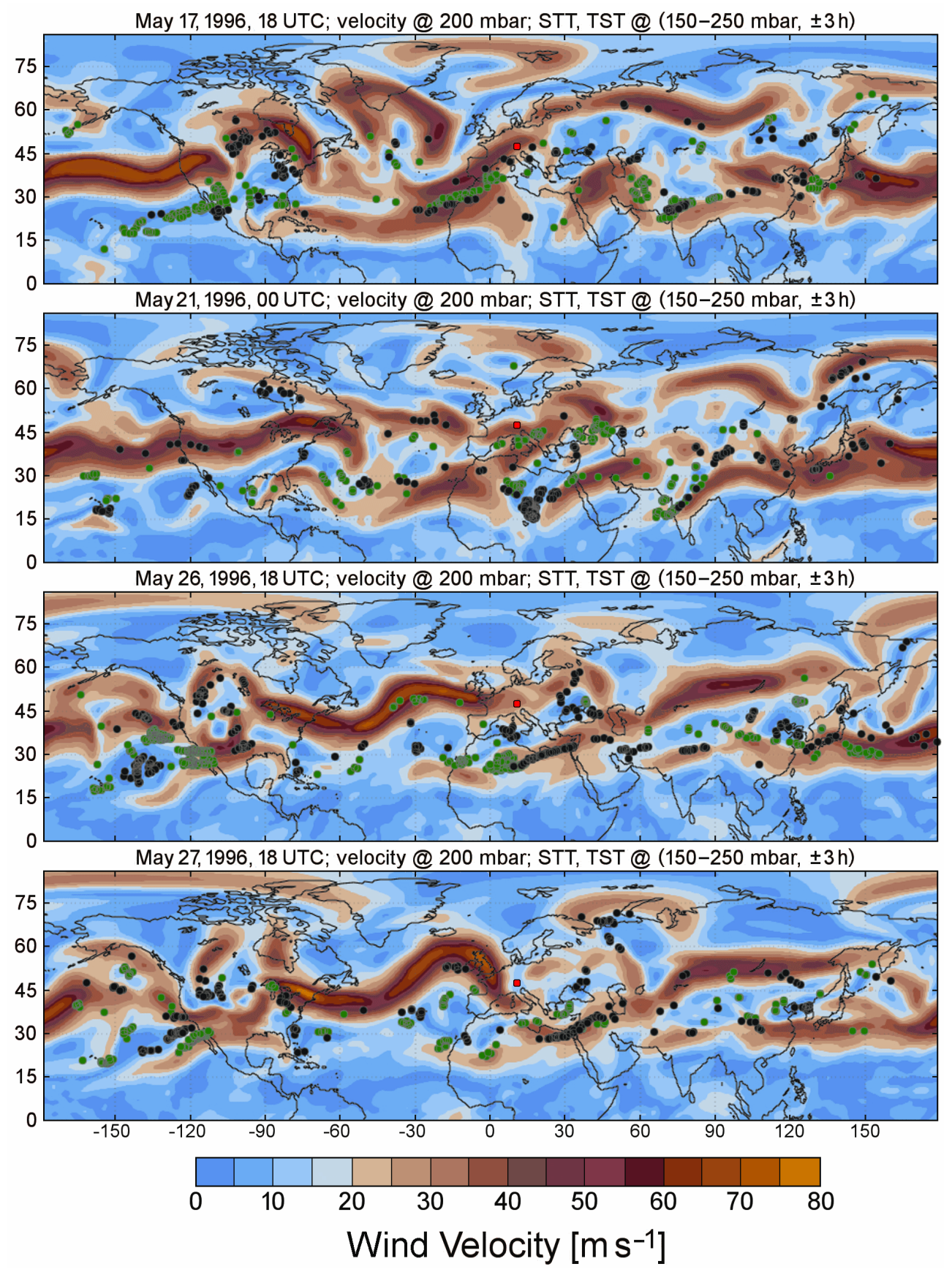

Fig. 7. Selected examples of the ECMWF/LAGRANTO visualizations of the jet streams for Case 1; the position of Garmisch-Partenkirchen is marked with a red dot next to the centre of each panel. The wind speed is colour coded. The positions where trajectories revealed STT or TST between 150 and 200 mbar are marked by green and black dots, respectively.

being vertical displacements due to orographic lifting of the sonde. In addition, frequent measurements with the big aerosol lidar were made during this field campaign, yielding information on potential contributions from remote boundary layers. Due to the availability of all these complementary measurements we discuss this period in particular detail. In the following we present four examples from the period dur- ing which all system were operated. We describe here mostly the analysis for 27 May, more information on the other days being included in (Trickl et al., 2009).

After a frontal passage on 23 May a long high-pressure zone formed that extended from the region south of Newfoundland to $30^{\circ} \mathrm{E}$ on 24 May. As seen in the other five (and many more) cases the occurrence of a stratospheric intrusion 

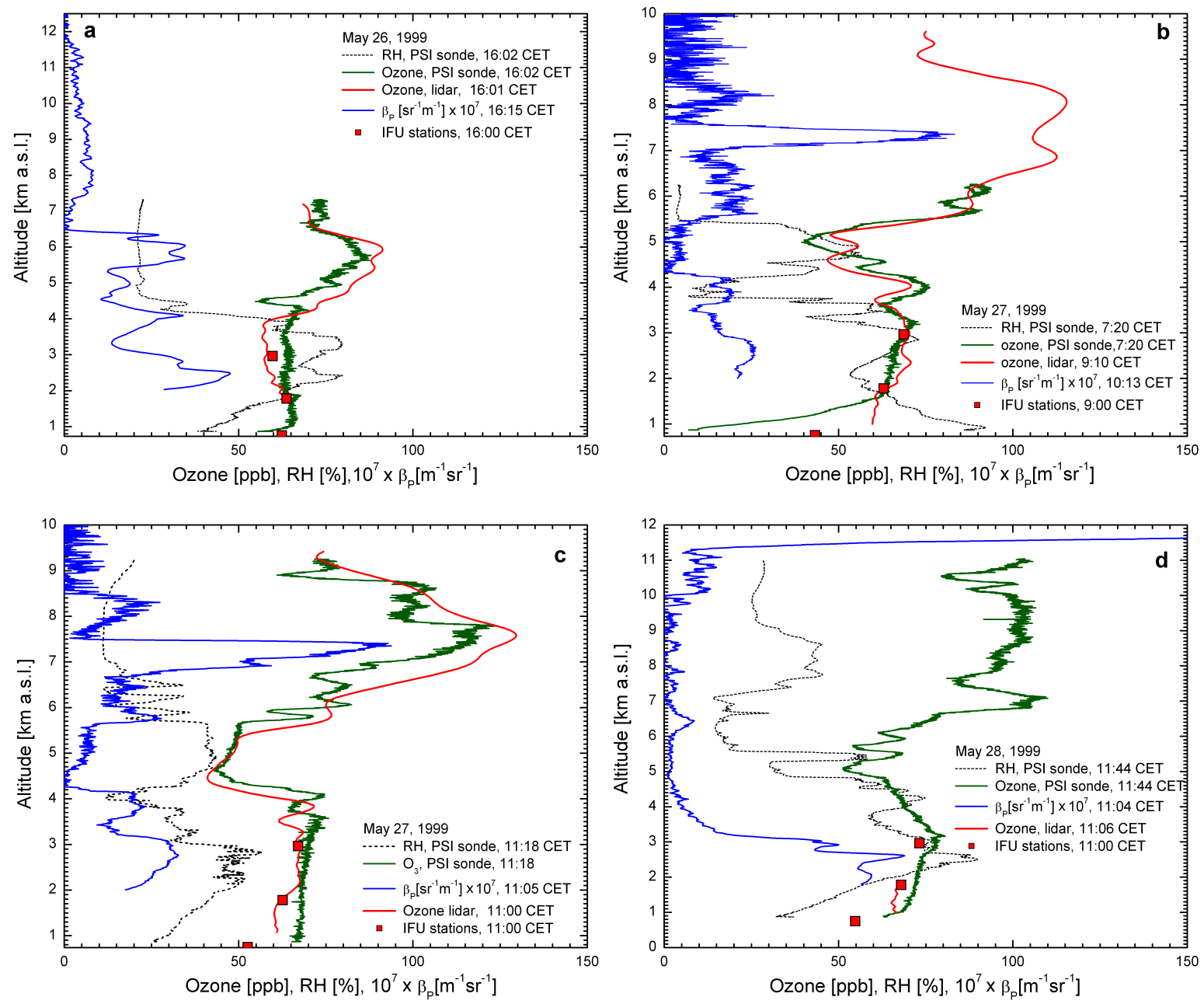

Fig. 8. Examples of lidar, sonde and station measurements from the VOTALP II "Munich" field campaign, (a) 26 May 1999 , around 16:00 CET; (b) in the morning of 27 May 1999; (c) around noon on 27 May 1999; (d) before noon on 28 May 1999. Shown are ozone (from lidar, PSI sonde, stations), relative humidity (RH, from PSI sonde) and the aerosol backscatter coefficient $\beta_{P}$ derived from the measurements with the "NDACC" aerosol lidar at large elevation angles of at least $45^{\circ}$.

would have been be expected during the transition to high pressure. We suspect that the intrusion was shifted to the east in the rapid eastward air flow north of the Alps.

The analysis in our previous study (Trickl et al., 2003) showed contributions to the high-ozone layer from several source regions in the US for 26 May and 27 May. The measured ozone concentrations in the US did not suffice to explain mixing ratios of more than $80 \mathrm{ppb}$. Also some convective activity was discussed. However, as in the first case, the trajectories for these days and also later show a strong midand upper-tropospheric component entering from the Pacific.

\subsubsection{Observations}

Due to the preparations for the field campaign no lidar measurements were made on the first two days of this highpressure period. The measurements were started in the early afternoon of 26 May, and immediately showed the high-ozone layer that was subsequently observed over many days. Figure 8a shows one example of soundings on 26 May at about 16:00 CET, when the first PSI ozone sonde was launched. The agreement between lidar and sonde is not perfect which indicates some spatial inhomogeneity of that ozone layer. The lidar data are confirmed up to $3 \mathrm{~km}$ by the measurements at the nearby local monitoring stations, whereas the sonde should have departed more to the east.

Above $4 \mathrm{~km}$ elevated ozone is correlated with low humidity and, in part, with aerosol. Both the ozone lidar (affected by a small light leak in the receiver box during that campaign) and the PSI data, unfortunately, end just above $7 \mathrm{~km}$. However, the aerosol lidar detected significant traces of particles between $7.3 \mathrm{~km}$ and $11.7 \mathrm{~km}$, the latter value agreeing with the tropopause levels determined by the Munich radiosonde (11.6 km at 12:00 UTC and $11.8 \mathrm{~km}$ at 24:00 UTC). 
May 27, 1999, 5-15 CET, 5-9 km a.s.l.
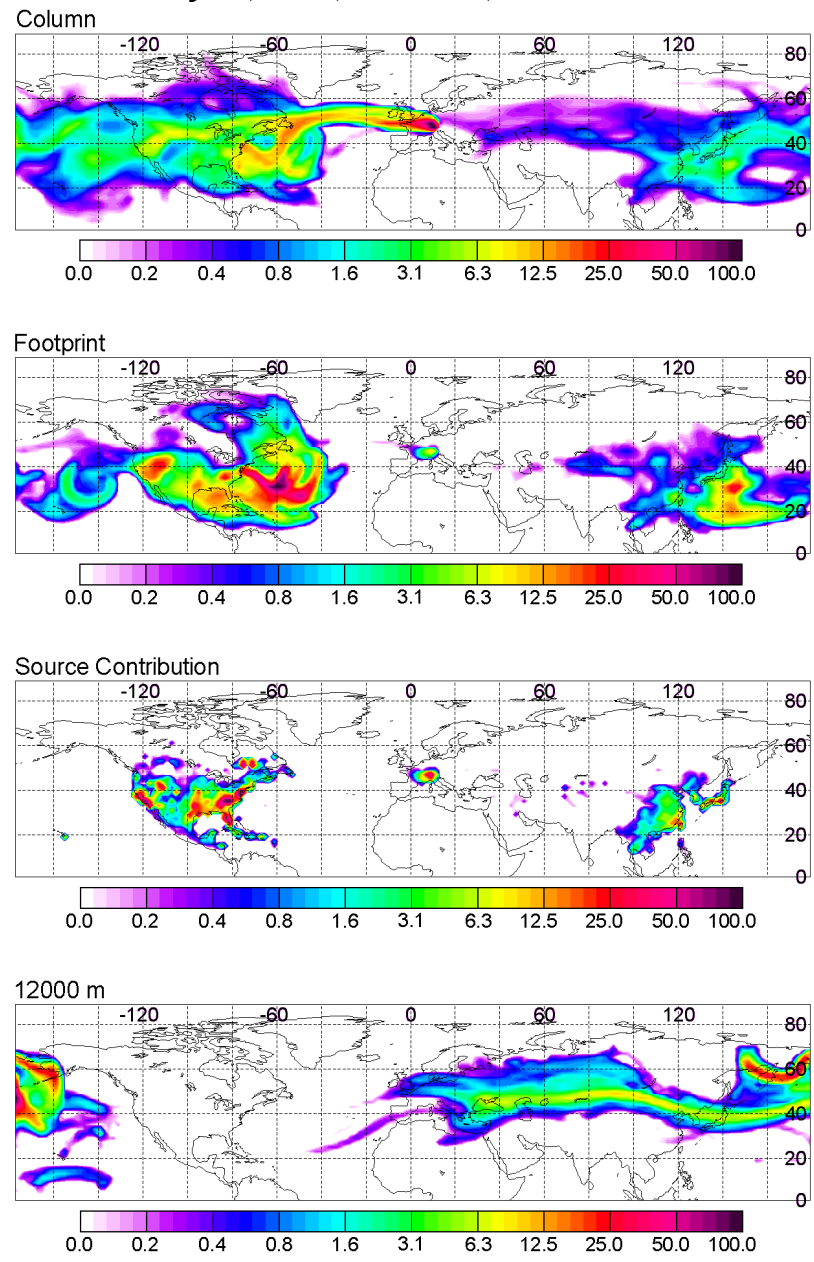

Fig. 9. Fifteen-day backward simulation with FLEXPART for 27 May 1999, between 05:00 and 15:00 CET, corresponding to the measurements in Fig. 8b and c (see Fig. 2 for more details).

Figure $8 \mathrm{~b}$ and $\mathrm{c}$ show very high ozone and aerosol values on 27 May 1999, correlated with low relative-humidity values down to $5 \%$ (please, note in Fig. 8c the vertical offset of the lidar and the sonde data above $3.3 \mathrm{~km}$ ). The aerosol peaks for the 532-nm measurements reach almost $10^{-5}(\mathrm{~m} \mathrm{sr})^{-1}$, which is quite remarkable for the free troposphere and corresponds to a visual range of less than $10 \mathrm{~km}$. Such values are almost one order of magnitude higher than typical values for aerosol structures related to intercontinental transport, even in fire plumes from the US observed during strong fire years (see Sect. 4).

The fourth example (Fig. 8d) is from a period on 28 May (not analysed in our earlier publication) between an earlymorning thunderstorm and rain in the afternoon. There was much less aerosol, but, still, the ozone values were high and the corresponding humidity was low. Before the thunderstorm the ozone values had reached roughly $150 \mathrm{ppb}$ (03:00 CET).

\subsubsection{Retroplume analysis (FLEXPART)}

As a first step for extending the analysis with respect to that by Trickl et al. (2003), a fifteen-day FLEXPART backward simulation was carried out for the high-ozone layer between 5 and $9 \mathrm{~km}$ on 27 May (Fig. 9). The result for $12000 \mathrm{~m}$ looks similar to that in Fig. 3, indicating a possibly strong contribution from a stratospheric intrusion over the Northern Pacific and reproducing the second, highly confined branch reaching back to the Mediterranean Sea. However, in this case some Asian air pollution was mixed into the air stream. It is interesting to note that the backward simulations show significant contributions from several source regions in the entire US not identified by the ten-day backward trajectories studied by Trickl et al. (2003), in particular California, which demonstrates the better coverage of remote areas by the retroplume results.

As for Case 1 the simulations were more recently extended to twenty days for all the times of the examples in Fig. 8a to $\mathrm{d}$ in order to harden the stratospheric influence and to obtain a better estimate of the role of the Asian emissions based on the potentially better overlap with the countries in the Far East.

In Fig. 10 we give an overview of the vertical distributions of the stratospheric fractions calculated for the four measurements shown in Fig. 8. Again, the highest STT fractions extracted from the FLEXPART calculations are reached within the earliest days. We, thus, show results only for days -20 to -15 . Clearly, the maximum stratospheric fractions for all four measurements discussed are higher than those for Case 1, in qualitative agreement with the, in part, much higher observed ozone concentrations. A comparison of the two profiles for 27 May (Fig. 10b) with the measured ozone and aerosol profiles, despite nicely reproducing the main features, indicates some noise component in the numerical results: There is less difference between the two measurements than between the two simulated fraction profiles. Despite the fine structure seen in the experimental and modelled results in the range between $5.5 \mathrm{~km}$ and $9 \mathrm{~km}$ the transport pathway does not change much. Differences are only seen over Asia, as indicated by the broadening of the plume section for $12000 \mathrm{~m}$ in Fig. 9.

In Fig. 11 we give three examples of retroplume summaries for specific layers on 27 May at 11:00 (Fig. 8c), one below the range with elevated stratospheric fractions, two within this range. In particular, in the range of the strongest peak in the aerosol profiles the FLEXPART stratospheric fraction is highest (7000 to $7250 \mathrm{~m}$ ), and elevated fractions extend over more than 17 days. The FLEXPART particle clusters in the upper boxes of the two lower panels do not suggest shallow STT.

Also import from the East Asian PBL is seen. From the emission sensitivity "footprints" it is obvious that PBL contact over East Asia peaks for air masses arriving over Garmisch-Partenkirchen in the range between $7.25 \mathrm{~km}$ and 

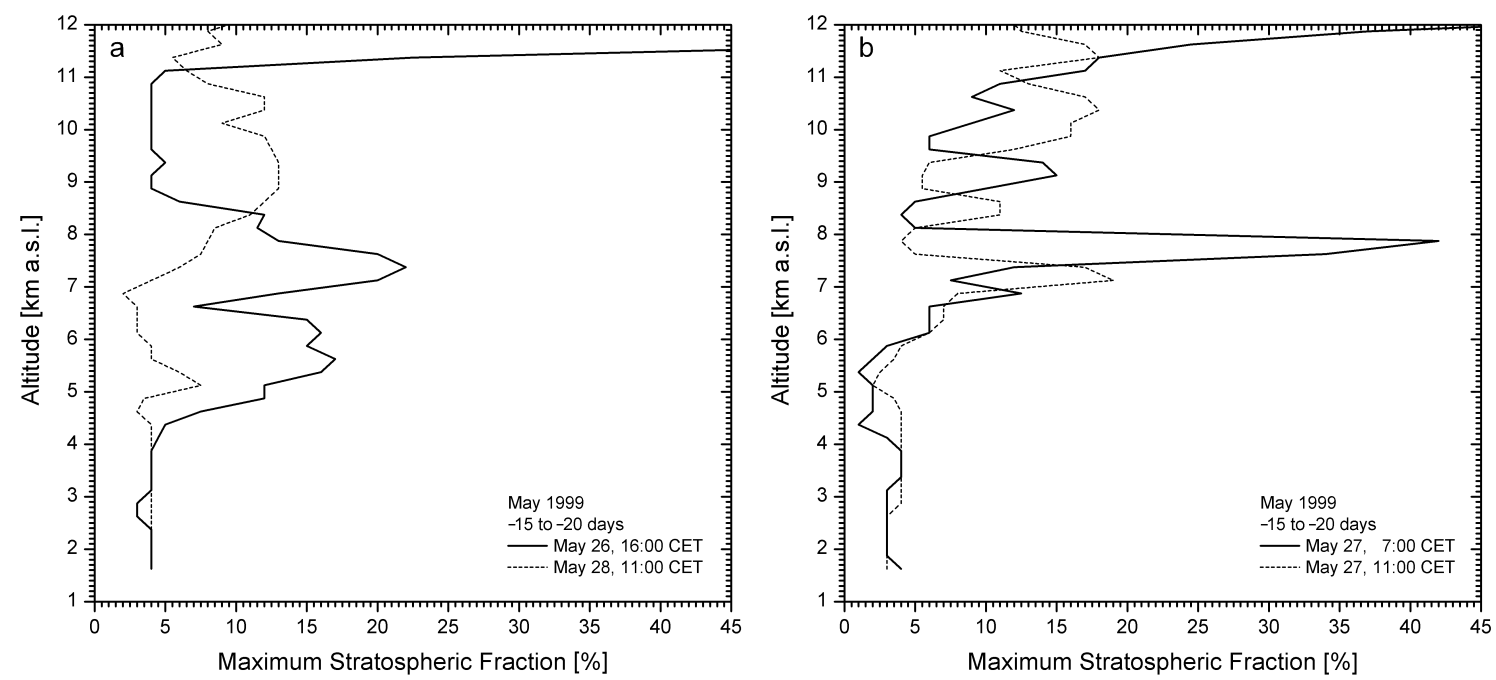

Fig. 10. Vertical distribution of the maximum stratospheric fraction in the twenty-day FLEXPART retroplumes calculated for the four measurements in Fig. 7, extracted from days -20 to - 15: (a) 26 May and 28 May, (b) 27 May.

$8 \mathrm{~km}$, i.e., in the altitude range of the big aerosol peak in Fig. $8 \mathrm{~b}$ and c. The FLEXPART analysis shows contact with the lower troposphere over Asia for the period before day -9 , when the lowermost cluster in the 7000-m-to-7250$\mathrm{m}$ altitude panel in Fig. 11 is centred at $2 \mathrm{~km}$. The export from East Asia proceeded via (presumably dry) prefrontal rise. The Asian influence is confirmed by the vertical distribution of the emissions transported to GarmischPartenkirchen, (Fig. 12; see in particular $\mathrm{SO}_{2}$ ). The backward plume overlaps with the desert regions. The aerosol images from the Total Ozone Mapping Spectrometer (TOMS, http://toms.gsfc.nasa.gov/aerosols/aerosols.html) reveal pronounced dust outbreaks in the Takla Makan or Gobi deserts during the entire month of May. It is, thus, likely that at least the big aerosol peak in Fig. $8 \mathrm{~b}$ and c between 7 and $8 \mathrm{~km}$ is caused by dust from the Asian deserts. The satellite images do not show any other significant source of aerosol in sufficient vicinity to the FLEXPART plume.

Despite the rather convincing FLEXPART STT fractions the particularly high ozone values around $7 \mathrm{~km}$ on 27 May could suggest the presence of an additional component from Asian emissions. However, the FLEXPART results reveal even stronger Asian influence for 26 May (Supplement, Fig. $\mathrm{S}_{2}$ ), but lower ozone levels were observed over Garmisch-Partenkirchen. On 26 May, the aerosol contribution is lower (Fig. 8a) which indicates less influence from the deserts. The Asian influence seems to be higher in the altitude range with the highest aerosol backscatter coefficients $(5.5 \mathrm{~km}$ to $6.5 \mathrm{~km})$ whereas in the lower-aerosol range between $7.2 \mathrm{~km}$ and $11.9 \mathrm{~km}$ also some North American fraction was found. On 28 May (Fig. 8d) the influence of the continental boundary layers seems to be low. Here, very likely, the stratospheric influence dominates.
In summary, we conclude also for the high-ozone layer observed in this case study the presence a highly significant stratospheric component, however, interleaved with PBL air during certain periods. The transport pattern resembles that in Case 1.

\subsubsection{Jet-stream and Lagrangian STE analysis (LAGRANTO)}

Also for Case 2 an attempt was made to relate the long part of the FLEXPART backward plume, which reached back to the Mediterranean Sea, to vertical exchange (STT) along the subtropical jet stream. Again, a good general agreement with the plume component in the 12-km panel of Fig. 9 is found (Supplement, Fig. $\mathrm{S}_{3}$ ). However, over a major part of Asia less STT events are marked than in the images for Case 1. This could, in part, be due to the restrictive selection criteria (see Sect. 2.2). In particular, the potential vorticity threshold of 2 pvu might be too high for the subtropics (Folkins and Appenzeller, 1996; Gouget et al., 1996).

\subsection{Case 5: 21 to 24 July 2001}

\subsubsection{Observations}

The lidar measurements between 21 and 24 July (Fig. 13) yielded a particularly nice example of the May-1996 type (Case 1), in an analogous way related to a high-pressure zone moving into Central Europe. The ozone layering is, again, typical of this kind of weather situation, with stratospheric air (S) descending towards the PBL in the early phase, low$\mathrm{O}_{3}$ air from the subtropics above this layer (SA) and air from beyond the Atlantic above $4 \mathrm{~km}$ (see Sect. 3.1).

The temporal development above $4 \mathrm{~km}$ starts with the arrival of PBL contributions from the US. The principal source 
Retroplume Summary for May 27, 1999, 11 CET $3000-3250 \mathrm{~m}$

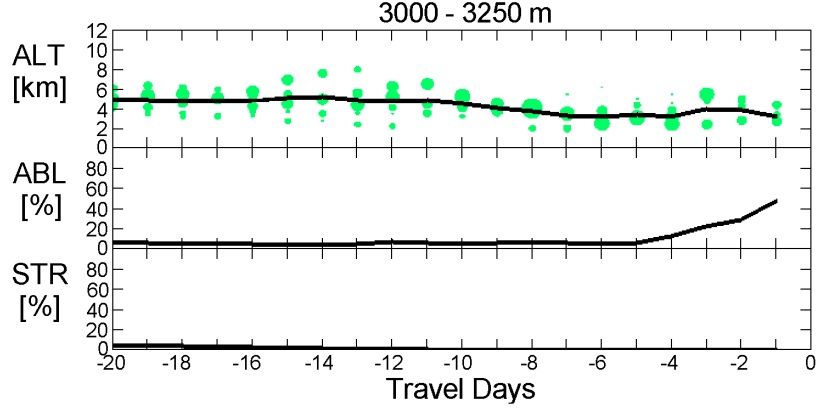

$6250-6500 m$

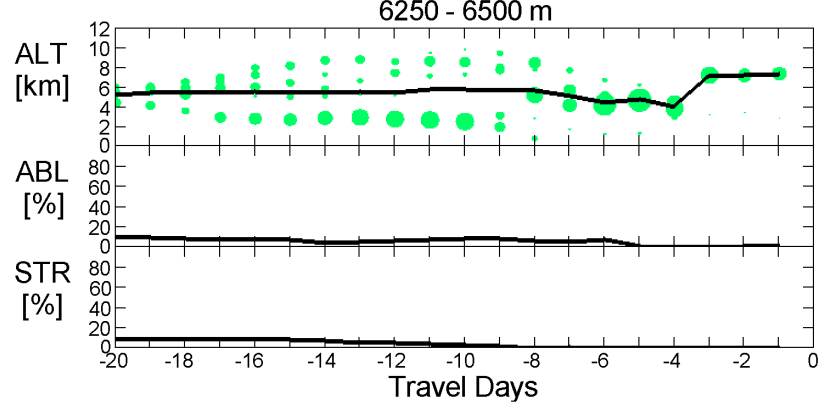

$7000-7250 \mathrm{~m}$

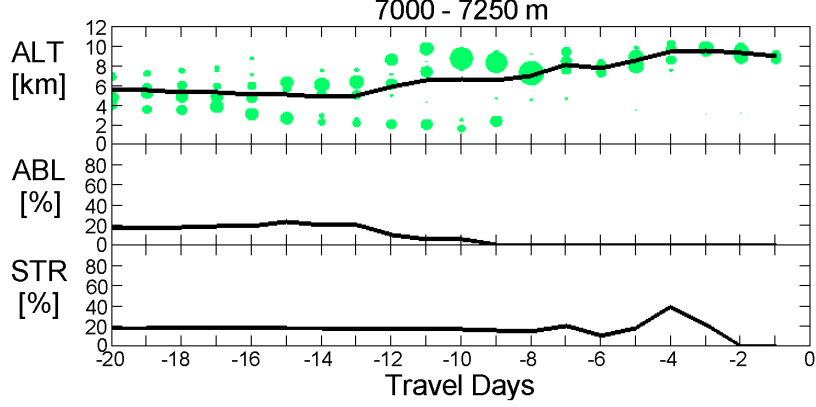

Fig. 11. Retroplume time-height sections from the twenty-day simulation for three selected altitude ranges above GarmischPartenkirchen initiated at the time of the lidar measurement in Fig. 8c; for details see Fig. 5 and Sect. 2.2. The simulations for Fig. 8b look similar.

region was first the north-eastern part of the US, later there was also input from other regions. Again with a delay of about two days there was a conspicuous ozone increase between 6 and $8 \mathrm{~km}$, here to values of about $120 \mathrm{ppb}$. The correctness of the measurements was verified by a comparison with the Hohenpeißenberg ozone sonde on 23 July 2001, launched at 05:41 CET (difference at the ozone peak at $7.5 \mathrm{~km}:+7 \mathrm{ppb}$ for the lidar). From the ozone structure we distinguish several layers. The analysis focusses on the three layers labelled in Fig. 13 as 1 to 3.

Since low humidity had been found in the analogous cases we analysed the MOZAIC data for Frankfurt and radiosonde data from the surrounding stations Payerne, Stuttgart and Munich. No suitable MOZAIC flight was found for the short period of Layer 3. The sonde data, indeed, show dry layers

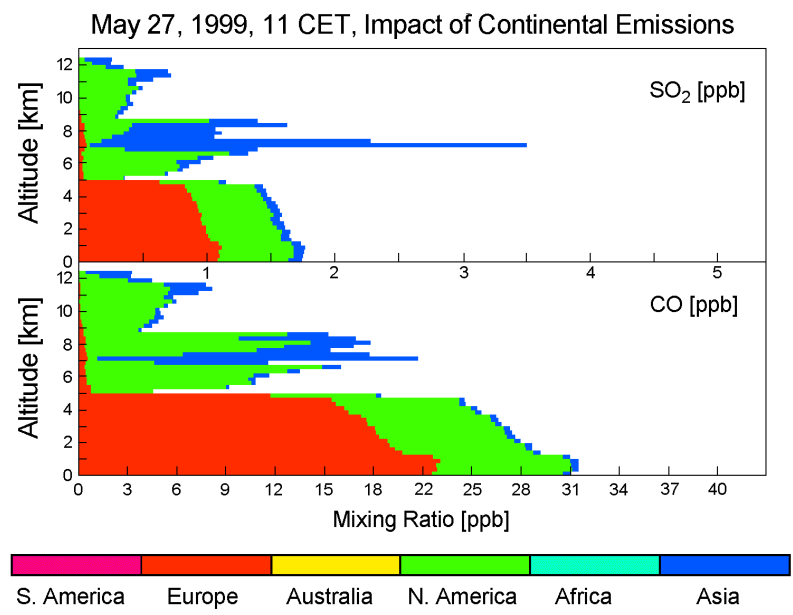

Fig. 12. Vertical distribution of FLEXPART $\mathrm{SO}_{2}$ and $\mathrm{CO}$ emission tracers from the different source continents above GarmischPartenkirchen, calculated for the time of the lidar measurement on 27 May 1999, shown in Fig. 8c (twenty-day simulation); Asian influence is found in the altitude range around $8 \mathrm{~km}$.

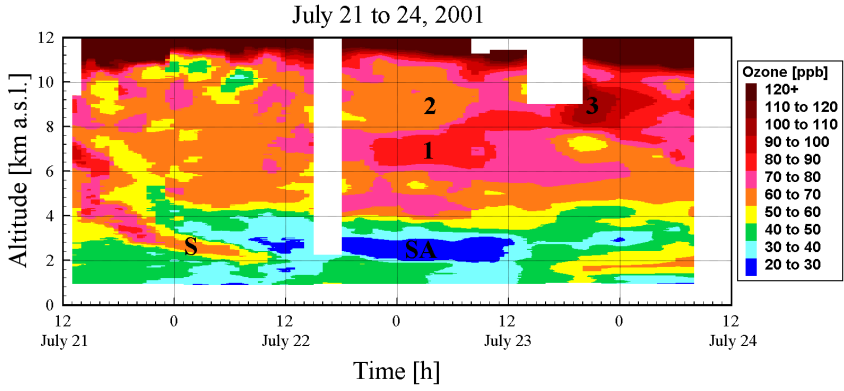

Fig. 13. Ozone sounding series in July 2001 at the beginning of a high-pressure period;S marks a stratospheric air intrusion, SA air from the subtropical Atlantic, the layers marked with the labels 1, 2 and 3 are discussed in the text. The time scale is given with respect to 00:00 CET on 21 July.

(10-20\% relative humidity). The situation is quite complicated due to the strongly altitude- and time-dependent wind direction (see Figs. 14, 15). We, therefore, shift the description to the Supplement.

\subsubsection{Vertical position of the air stream (FLEXTRA trajectories)}

Because of the spatial confinement of the most relevant air masses a particularly clear picture of the three-dimensional transport path from $140^{\circ} \mathrm{W}$ to Garmisch-Partenkirchen is obtained from ten-day FLEXTRA trajectory plots. The trajectories yield the best information on the vertical position of the air streams corresponding to Layers 1 to 3 , at least within their ten-day time span. Two examples for the period of Layers 1 to 3 are shown in Figs. 14 and 15. An onset of air-mass import from the Pacific is observed in the 

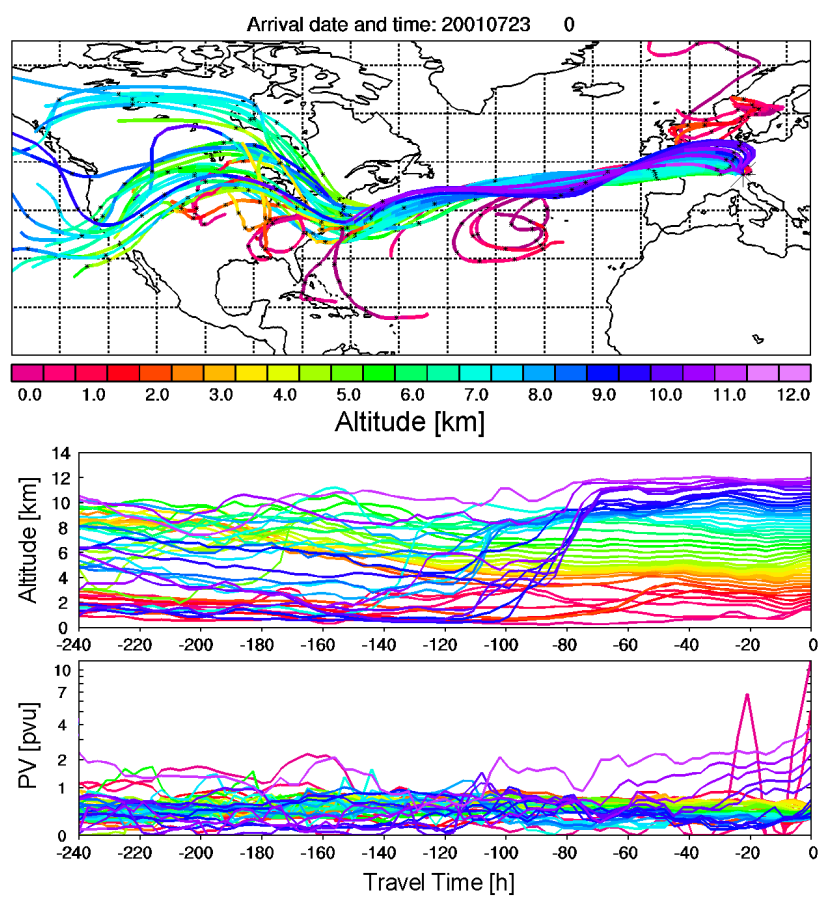

Fig. 14. Ten-day FLEXTRA backward trajectories initiated above Garmisch-Partenkirchen on 23 July 2001, 01:00 CET (corresponding to labels 1 and 2 in Fig. 13); the colour code in the upper panel describes the altitude at a given time. In the lower two panels it indicates the altitude at the location of Garmisch-Partenkirchen $(t=0)$. The asterisks on the individual trajectories mark the 00:00 UTC positions.

afternoon of 22 July, for altitudes above the lidar between 6 and $8 \mathrm{~km}$ a.s.l. The advection pathway covers parts of Canada and the Northern US. For the 01:00-CET calculation (Fig. 14) the upper-tropospheric trajectories (Layer 2) mostly correspond to air masses ascending from the PBL over North America and the western part of the Atlantic. The trajectories for Layer 1 stay in the upper troposphere and even slightly ascend backward in time as they approach the Pacific. The situation changes in the afternoon of 23 July, when most trajectories above $5 \mathrm{~km}$ stay at high altitudes and end over the Pacific (Fig. 15). There is some indication of separate trajectory bundles for Layers 1 and 3 (below and above $8 \mathrm{~km}$ a.s.l). The potential vorticity south of Alaska is less than 1 pvu suggesting the absence of a local intrusion in this area.

\subsubsection{Retroplume analysis (FLEXPART)}

Fifteen-day backward simulations with FLEXPART were carried out for all the three layers. We only show the results for Layer 3 (Fig. 16). The simulations for the other two layers look similar, but without a clear contact with the East Asian PBL within fifteen days and potential STT for Layer 1 over the Atlantic between $15^{\circ}$ and $45^{\circ} \mathrm{N}$.
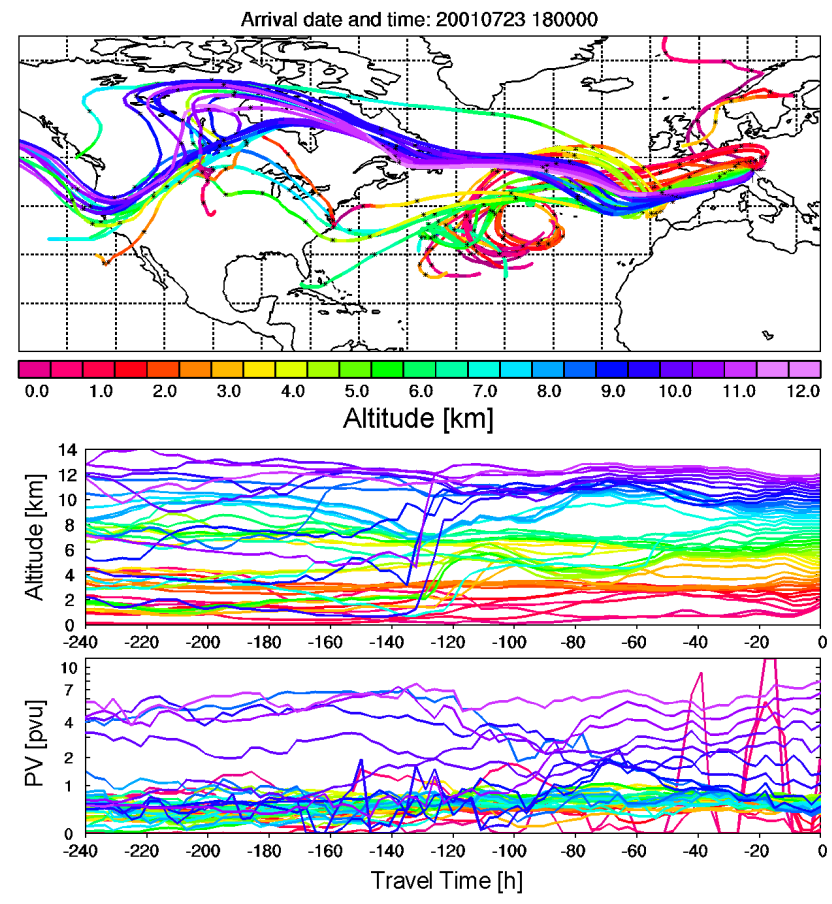

Fig. 15. Same as Fig. 14, but for 23 July 2001, 19:00 CET (corresponding to label 3 in Fig. 13); some of the upper-tropospheric trajectories reach altitudes above $12 \mathrm{~km}$ during the earliest period.

The results in Fig. 16 for $12000 \mathrm{~m}$ altitude, again, indicate potential STT over the Pacific. As in the first two cases, intersections with this level are seen all the way back between the Pacific and the East Atlantic (more than once around the globe). The particle band for for $12000 \mathrm{~m}$ starts exactly in the region where the trajectories in Fig. 15 leave the panel. This slice of the backward plume follows the maxima of the column sensitivity even over Asia, suggesting a single, almost coherent air stream all around the globe, again following the maximum of shallow STT displayed by Sprenger et al. (2003). Moderate PBL contributions from both North America and East Asia are seen.

For three times on 23 July corresponding to Layers 1 to 3, 04:00 CET, 07:00 CET and 22:00 CET, twenty-day simulations were performed, which yielded both a better estimate of the potential Asian influence and information on the approximate vertical position of the plume. Just the results for 22:00 CET are presented here. The simulations for the earlier two times show elevated PBL contributions above $7 \mathrm{~km}$, increasing towards Layer 2 North American contributions dominate the emissions (see Fig. $\mathrm{S}_{5}$ in the Supplement). However, the vertical distribution of advected emissions does not explain why there is so much more ozone in Layer 1 than in Layer 2. However, in Layer 1 an elevated single-day stratospheric influence of up to $12 \%$ is seen in the FLEXPART results. By contrast, for Layer 2 rather low stratospheric fractions are obtained for the preceding twenty 
July 23-24, 2001, 18-3 CET, 8-10 km a.s.I.
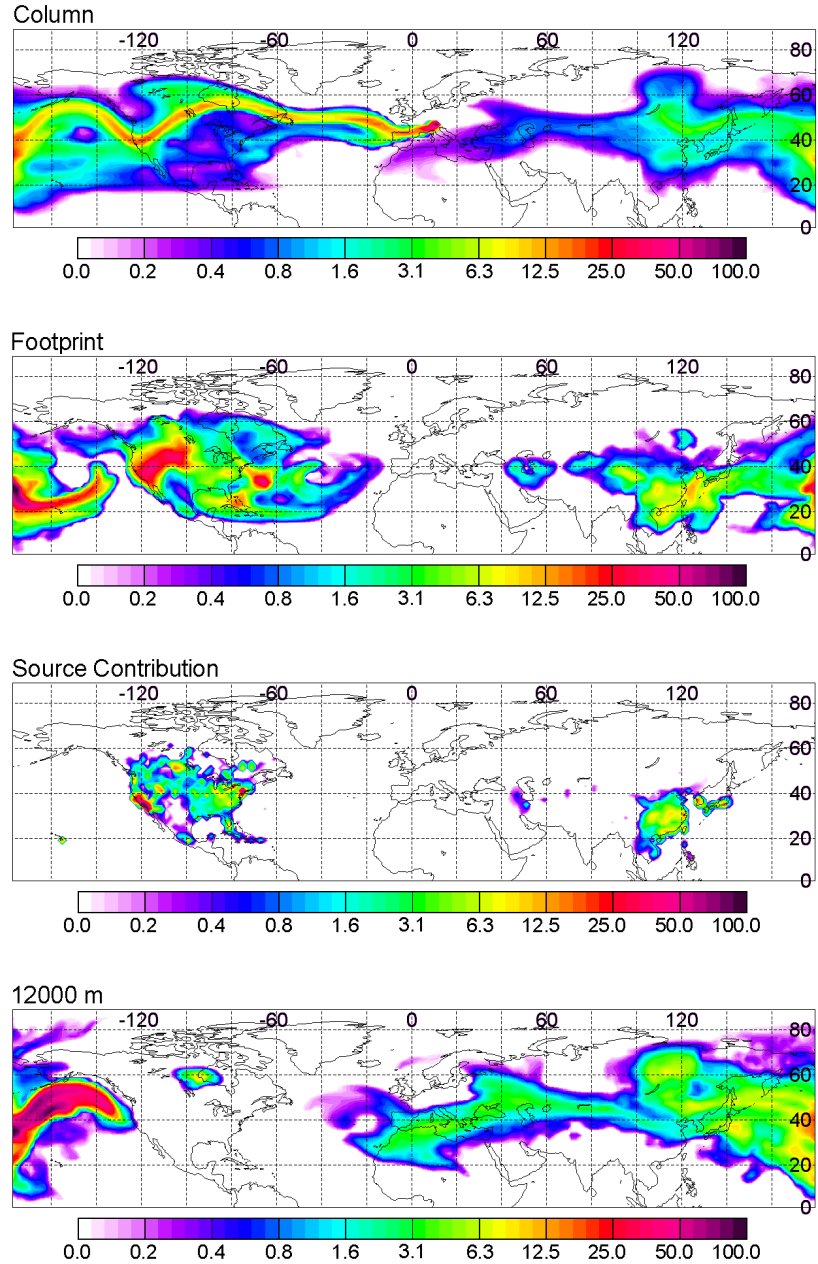

Fig. 16. FLEXPART fifteen-day backward simulation for retroplumes released between 23 July 2001, 18:00 CET, to 24 July 2001, 03:00 CET, and between 8 and $10 \mathrm{~km}$ a.s.l. above GarmischPartenkirchen (Layer 3 in Fig. 13; see Fig. 2 for more details).

days. We conclude that the high ozone values in Layer 1 are mostly due to the stratospheric component.

In the case of layer L3 (22:00 CET), where the highest ozone concentration is found, the stratospheric contribution clearly dominates. Figure 17 shows a vertical distribution of the maximum single-day FLEXPART stratospheric fractions for the backward time intervals five to ten and ten to twenty days as extracted from the retroplume analysis for 22:00 CET. These time intervals cover most of the relevant stratospheric input. The pronounced stratospheric peaks correlate well with the observed ozone maxima for 22:00 CET on 23 July. The stratospheric fraction for Layer $3(9 \mathrm{~km})$ is particularly high (63 and $75 \%$, respectively, for the two backward time periods chosen). Given this high fraction, the observed peak ozone mixing ratios of about $120 \mathrm{ppb}$ look somewhat low remembering the findings for the other cases

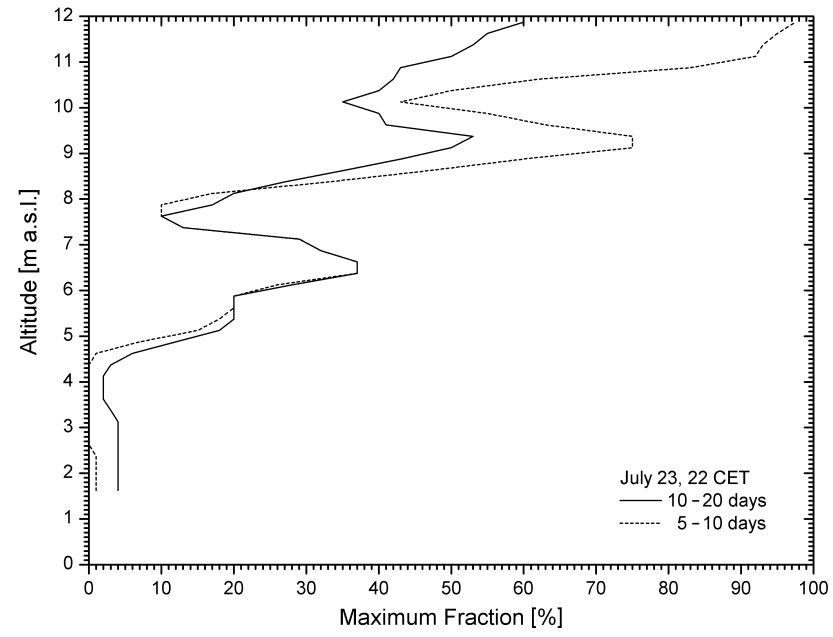

Fig. 17. Vertical distribution of the maximum stratospheric fraction in the retroplume calculated for $23 \mathrm{July,} \mathrm{22:00} \mathrm{CET,} \mathrm{for} \mathrm{two} \mathrm{differ-}$ ent backward time periods.

for which lower stratospheric fractions were found. It is interesting to note that the highest fraction corresponds to STT on day -6 , when the rapidly travelling plume was located roughly south of Alaska and where it reached its highest mean altitude during the entire twenty-day period of almost $12 \mathrm{~km}$. This is in some contrast to the PV results in Fig. 15 based just on trajectories.

The time-altitude plot for Layer 3 (not shown) shows four partial clusters of the plume, the upper three always staying above $6 \mathrm{~km}$ and the uppermost one never getting below $10 \mathrm{~km}$. This confirms the tendency seen in the trajectory plot (Fig. 15) and, again, suggests rather shallow STT in an uppertropospheric air stream almost all the way around the globe (starting at $-4 \mathrm{~d}$ ).

The vertical distribution of emissions for Layer 3 (Fig. 18) show only half the mixing ratios calculated for Layers 1 and 2. But they include a much higher Asian fraction, as already indicated in the fifteen-day simulations. A moderate North American spike at $8 \mathrm{~km}$ is likely to be an extension of Layer 1.

\subsubsection{Jet-stream and Lagrangian analysis (LAGRANTO)}

Examples of the LAGRANTO simulations for Case 5 are shown in Fig. 19. For this case the FLEXPART plume can localized rather well to about 11 days backward in time. As a consequence we marked the mean single-day position extracted from the retroplume analysis for layer L3 on the three lowest panels with red crosses. Next to the cross in the lowest panel (south of Alaska, day -6) only three green circles are marked. This number of STT events looks low in comparison with expectations for the STT in this region from the previous section. Again, we suspect that this low number 


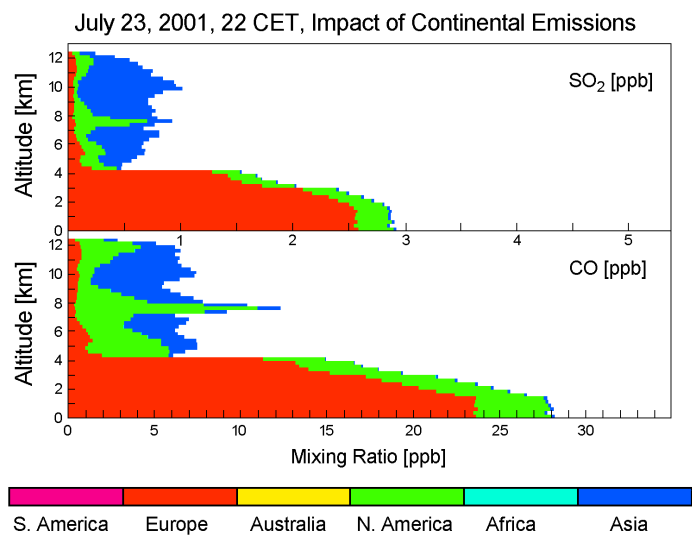

Fig. 18. Vertical distribution of FLEXPART $\mathrm{SO}_{2}$ and $\mathrm{CO}$ emission tracers from the different source continents simulated for the lidar measurement on 23 July 1999, 22:00 CET (twenty-day simulation).

of number of STT events could be ascribed to the restrictive selection criteria for the LAGRANTO analysis.

For the earliest days the temporal spread of the FLEXPART plume is too high for positioning. The top panel reveals pronounced STT over Morocco, exactly where the backward tongue in the 12000-m panel in Fig. 16 ends.

\section{Discussion and conclusions}

The extended backward analyses presented in this paper have added some significant information on mid- and uppertropospheric dry high-ozone layers rather consistently observed with the lidar roughly two days after the beginning of high-pressure periods. The high-pressure zones under consideration typically enter Central Europe not extending too far to the north of our observational site in the Northern Alps (roughly $1000 \mathrm{~km}$ ), thus allowing for anti-cyclonic inflow of North American air masses around their northern edge during the early phase (Eisele et al., 1999; Stohl and Trickl, 1999; Trickl et al., 2003). As the high-pressure zone proceeds to the east a transition to straighter inflow from the Atlantic occurs at some altitudes in the free troposphere (see Figs. 14 and 15 as well as the column-sensitivity panels in Figs. 2, 3, 9 and 16) and the direct advection from beyond North America starts at altitudes typically above $5 \mathrm{~km}$. The North American air typically ascends from the PBL to the middle and upper troposphere by transport in warm-conveyor-belts (Stohl and Trickl, 1999) and the backward air parcels for the free troposphere horizontally almost coincide over a major part of the Atlantic. Over North America branching occurs at moderate altitudes. Considerable complexity is added by further prefrontal upward transport over the continent (Trickl et al., 2003).

The ozone-rich mid- and upper-tropospheric air streams are rather coherent and could be mostly followed from Europe backward to the Eastern Pacific even with trajectories.
Since the transport mostly takes place at high altitudes where turbulence is limited, the air masses follow quite well kinematic trajectories calculated from underlying ECMWF wind field. For very long travelling times there is a clear gain in information by using the FLEXPART analysis tools because of the much higher density of the numerical particles in the backward plume and because of including even low levels of turbulence as well as convection. The column-integrated emission sensitivities quite frequently stay astonishingly narrow even back to the Pacific. The main uncertainties, visible in the spreading of the plume farther to the west, are, e.g., related to the parameterizations. The uncertainties associated with the spreading backward in time also influence those of the calculated STT fractions that could be too low if freetropospheric air-mass mixing were overestimated (Trickl et al., 2010; and current studies). There is additional uncertainty about the STT fractions due the 2-pvu threshold chosen for latitudes above $30^{\circ}: 2$ pvu may be too high for achieving quantitative results in the subtropics (Folkins and Appenzeller, 1996; Gouget et al., 1996). The comparison with the jet-stream results is satisfactory since also here the ECMWF analysis is used.

The vertical distributions for the various output quantities almost perfectly match the lidar results in their layering, whereas the accuracy of calculated mixing ratios is not known. The model-based analysis reveals the presence of stratospheric contributions mostly entering the troposphere over the Pacific, Asia, and even farther to the west. For just a few of the high-ozone layers simultaneous air pollution import from East Asia and North America was suggested, which hardens the idea of an important stratospheric influence on the ozone increase in the majority of these layers. Their thickness and length varies considerably from case to case (Table 1). A particularly impressive example with longlasting high ozone is Case 6 (13-15 August 2001; Table 1), for which FLEXPART revealed a complete absence of emissions. In addition, a hemispheric simulation (Trickl et al., 2010) with the EURAD chemistry-transport model showed the almost complete absence of extra $\mathrm{CO}$ from emissions for the entire duration of the high-ozone layer. The transfer from the stratosphere into the, in part, rapidly traveling air streams is very likely relatively shallow on average ("shallow and medium folds" as defined by Sprenger et al., 2003).

The absence of emissions in several of these layers supports the conclusion of STT as the main source of the elevated ozone. The layers, being several kilometres thick, contain 80 to $150 \mathrm{ppb}$ of ozone after travelling around a major part of the northern hemisphere. This underlines the importance of the underlying mechanism of STT. The humidity in these layers is low, but not negligible, which indicates a contribution of tropospheric air even in the centre of these sometimes quite thick layers. A tropospheric influence is obvious for the cases with aerosol observations.

Two branches are seen that vary in mutual importance from case to case. From our model analysis we cannot 

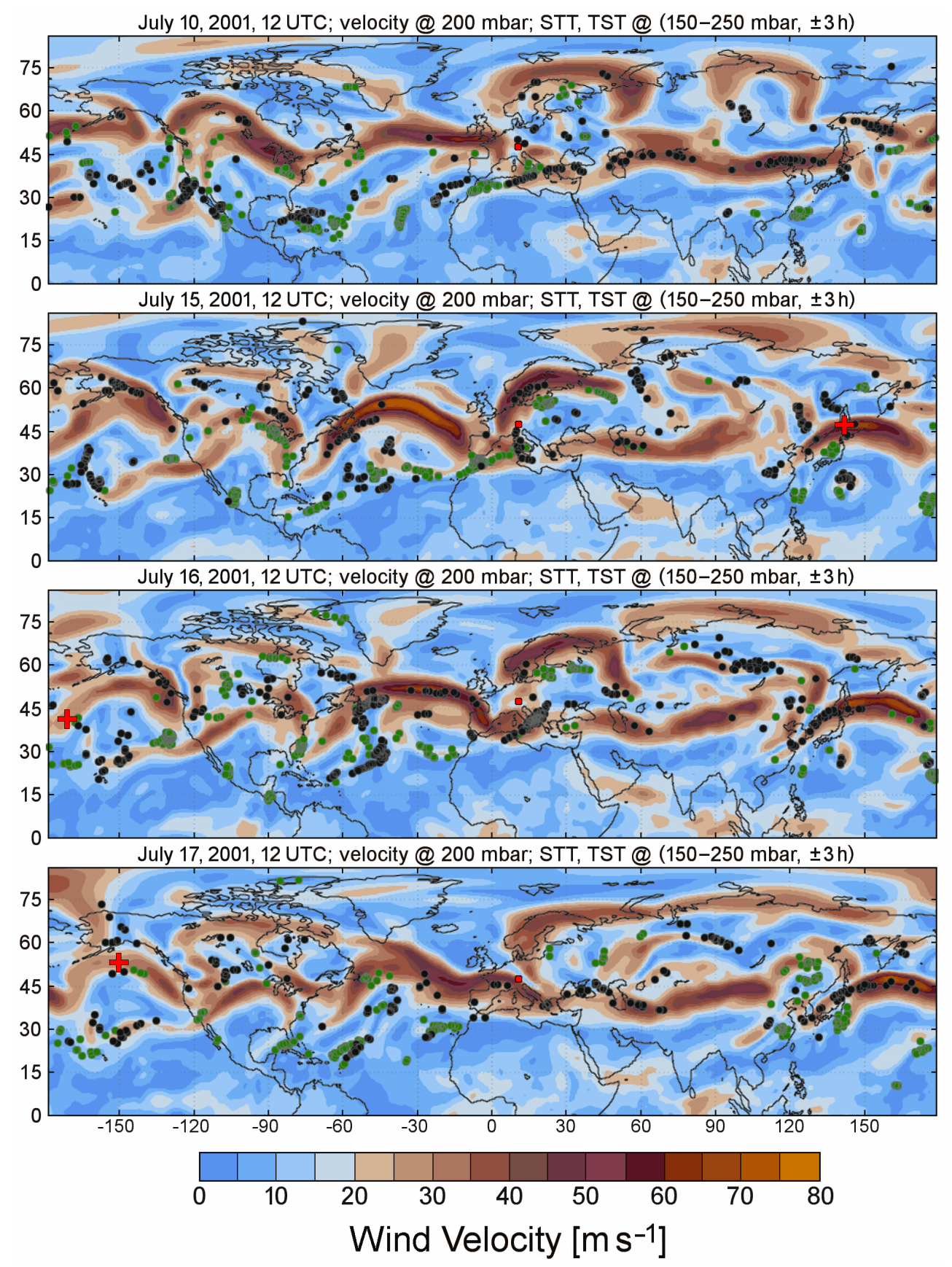

Fig. 19. Selected examples of the ECMWF/LAGRANTO visualizations of the jet streams for Case 5; the position of Garmisch-Partenkirchen is marked with a red dot next to the centre of each panel. The mean single-day position of the uppermost FLEXPART cluster is marked with a red cross for the days corresponding to panels 2 to 4 . The wind speed is colour coded. The positions where trajectories revealed STT or TST between 150 and 200 mbar are marked by green and black dots, respectively.

distinguish the branching ratio. The first branch corresponds to inflow from stratospheric intrusions over the Northern Pacific not deeply penetrating the troposphere. Such a contribution was found in two of the six cases. The other branch is formed by air masses travelling around the globe between $30^{\circ}$ and $40^{\circ} \mathrm{N}$ within just fifteen days. The $12-\mathrm{km}$ results in the fifteen-day simulations cannot be seen as a full proof due to the moderate latitudes of that component. However, there is some evidence from the twenty-day analyses (in particular Case 5, 21-24 July 2001) and the LAGRANTO results that significant STT should have occurred also here. In fact, these air streams almost co-incide with the maximum of shallow 
and medium folds obtained by Sprenger et al. (2003). This latitudinal belt seems to overlap with the northern end of the subtropical jet stream on the north side of the Hadley cell, typically between $10^{\circ}$ and $30^{\circ} \mathrm{N}$. What is special in our results is that STT does not only occur in descending air tongues: A significant amount of stratospheric air is also caught in an air stream travelling to Europe within or next to the jet stream.

The subtropical jet is an almost persistent feature exhibiting a rather moderate wave structure (e.g., Krishnamurti et al., 1961; Koch et al., 2006). The Results in Figs. 7, S 3 (Supplement) and 21 confirm this behaviour. Its maximum is reached in winter and spring and it is vertically thin in comparison with the polar jet (Koch et al., 2006). The maximum of shallow STT along the subtropical jet stream follows this seasonality with its area of occurrence shrinking to the continents and the inflow regions during summer (Sprenger et al., 2003). The reported shallow-fold formation seems to be located more on its north side. This is confirmed in our analysis for Case 1, but is less clear for the other cases. This is a consequence of the reported counter-clockwise rotation of that air stream (e.g., Krishnamurti, 1961), in agreement with the findings for the mid-latitude jet (e.g., Danielsen, 1968). The downward transport usually starts in regions of acceleration (entrance region, Keyser and Shapiro, 1986). This can be sometimes seen in the LAGRANTO results presented in Sect. 3, in particular in Fig. 7. But there are also deviations and, as mentioned in Sect. 3.1, regions where upward and downward transport even seems to co-exist. This is not easy to understand and indicates a considerable complexity of these processes. The complexity is enhanced by occasional contact with other jet streams. Due to the selection criteria the STT and TST events marked in Figs. 7, $\mathrm{S}_{3}$ (Supplement), and 19 do not give a full coverage of the trans-tropopause transport. This includes selecting 2 pvu for the tropopause instead of 1 pvu one and less as discussed by Folkins and Appenzeller (1996), Gouget et al. (1996) and Cammas et al. (1998). Zachariasse et al. (2000) also found low potential vorticity, but ascribed this fact to mixing induced, e.g., by clear-air turbulence.

Sprenger et al. (2003) conclude very high folding frequencies of almost $30 \%$ in this area that extends from North Africa to the Pacific (and even around the globe during the cold season), in agreement with the persistence of the subtropical jet stream. The reported lower STT penetration depth might, in part, be due to the lower jet-stream curvature (Keyser and Shapiro, 1986) and to a confinement of the jet to the upper troposphere in this area (Koch et al., 2006). Gouget et al. (1996) point out that the descending stratospheric air tongue analysed in their study was quasi-horizontal and that, in contrast to the deep mid-latitude jet front systems, the subtropical front was concentrated in a shallow layer. Cammas et al. (1998) found as many as 154 high-ozone episodes north of $15^{\circ} \mathrm{N}$ during MOZAIC flights between Europe and South America between August 1994 and April 1997. Zachariasse et al. (2000) also found low potential vorticity, but ascribed this fact to mixing induced, e.g., by clear-air turbulence.

The results of the jet-stream climatology derived by Koch et al. (2006) resemble the pathways obtained from the FLEXPART and ERA-40/LAGRANTO analyses for the cases examined in our study. The subtropical jet, on a seasonal average, proceeds northward over the Pacific and North America, ending between Iceland and the United Kingdom. This makes possible our surprising observations. The frequency of jet-stream occurrence along this band, in particular over North Africa, is higher in winter and spring than in summer. Four of our six observations took place in spring (Table 1), i.e., during a period favourable for the formation of such air streams. It will be interesting to see if, with a growing coverage of the cold season with lidar measurements in recent years similar middle- and upper-tropospheric ozone maxima can be identified also in winter. However, the hibernal flow pattern over the North Atlantic looks quite different from the situation in the six cases described here.

A comparison of the FLEXPART and LAGRANTO results for the early times also suggests that modelling of air flows around jet streams is quite reliable. However, it is difficult to compare the results on a daily basis because of the temporal spread of the backward plumes with time. Field experiments and forward transport model runs for analysing the vertical exchange across the subtropical tropopause and the long-distance propagation of stratospheric air intruded into the upper troposphere are desirable. Another open question is the deviation of the ERA-40 jet stream positions from the arrival pathway over the North Atlantic and Europe. According to the FLEXPART results the minimum travel time of these air masses once around the globe is of the order of fifteen days, corresponding to an average speed of roughly $30 \mathrm{~m} \mathrm{~s}^{-1}$. Therefore, it is reasonable to assume some propagation not too far away from the centre of the subtropical jet stream as indicated by the comparison of the model results.

Finally, the main open question remains that about the astonishing reproducibility of a pattern in the observations that is related to such an extremely long transport path. This question also addresses the behaviour of the northward spiralling of the subtropical jet stream. At this time, we cannot judge the importance of this kind of long-range transport for the tropospheric ozone over Central Europe. However, the modelling results by Sprenger et al. (2003) suggest that STT along the subtropical jet should be a major source of tropospheric ozone at least at other latitudes during a major part of the year.

The existence of aerosol in some of the layers indicates contributions from a remote PBL. In the most spectacular case (May 1999) the FLEXPART analysis suggests the presence of dust from the Takla Makan and Gobi deserts. However, it is difficult to quantify the impact of East Asian emissions. There are large uncertainties in the emission inventories (Ma and van Aardenne, 2004). This uncertainty is enhanced due to the strong positive trend in emissions in that 
region, with more than a doubling of the $\mathrm{NO}_{2}$ peak values from 1995 to 2004 (Richter et al., 2005; see also Ding et al., 2008). It would be helpful to obtain more observations with dominating East Asian influence. However, such cases are obviously difficult to find and we know of just two studies of Asian plumes reaching Europe after transport across the North Pacific, North America and the North Atlantic (Grousset et al., 2003; Stohl et al., 2007). The analysis of our measurements shows that most of these air streams contain some fraction of North American air pollution. However, a few aerosol observations in the free troposphere in our long-term series (Jäger, 2005) could be traced back to the Pacific area using FLEXTRA results (ATMOFAST, 2005; Jäger et al., 2006) and will be analysed further.

We found by trajectory analyses of free-tropospheric lidar measurements for several years that aerosol is a suitable indicator of PBL air, although its free-tropospheric abundance is mostly low (ATMOFAST, 2005; Jäger et al., 2006). This is perhaps due to washout in the WCBs during convectively lifting the PBL air to the free troposphere, or due to dilution in diverging air masses. In our free-tropospheric soundings available since 1992 the aerosol backscatter coefficients above $3 \mathrm{~km}$ have rarely exceeded the Rayleigh background at $532 \mathrm{~nm}$ (which corresponds to a visual range of $300 \mathrm{~km}$ at sea level) by more than $50 \%$, even during strong fire years in the US. Due to the high sensitivity of our NDACC lidar system (free-tropospheric threshold for aerosols: about $2 \%$ of the Rayleigh background) these structures are, nevertheless, clearly visible. Really strong aerosol signatures have only been detected above Garmisch-Partenkirchen during Saharan dust outbreaks, which typically reach up to $6 \mathrm{~km}$ (Jäger et al., 1988; Kreipl et al., 2001; Papayannis et al., 2008), and in boreal fire plumes, e.g., in August 1998 (Forster et al., 2001) and in July 2004 (during the ICARTT, Fehsenfeld et al., 2006, campaign, ATMOFAST, 2005).

The model results also reveal that there may be problems in quantitatively predicting the amount of ozone imported from the stratosphere into these rapid air streams. One possible reason could be the pronounced spatial and seasonal variation of ozone in the lowermost stratosphere ranging between 100 and $500 \mathrm{ppb}$ (Thouret et al., 2006). This is confirmed by our lidar measurements that occasionally show strong concentration changes above the tropopause within one to two hours.

The analysis may be further complicated by lightning. In all cases discussed by Trickl et al. (2003), which are also part of the present study, thunderstorms or large convective cells have been detected in areas where PBL air is lifted to the middle troposphere. Huntrieser et al. (2007) conclude from measurements over South America that the outflow from mesoscale convective systems may yield significantly enhanced ozone mixing ratios (roughly from $35-40 \mathrm{ppb}$ to 60-80 ppb in the case described) at distances of several hundred kilometres away from the source. A number of recent publications verify a significant ozone contribution from lightning-generated $\mathrm{NO}_{\mathrm{x}}$ for the US and adjacents marine regions (Beirle et al., 2006; Cooper et al., 2006; Liang et al., 2007; Schumann and Huntrieser, 2007; Singh et al., 2007; Sioris et al., 2007). Cooper et al. (2006) conclude from the large data set collected during the ICARTT campaign that most of the ozone enhancement over the Eastern US (excluding stratospheric contributions) in July and August 2004 was due to lightning-generated $\mathrm{NO}_{\mathrm{x}}$.

In many cases mixing of different contributions within or in the vicinity of frontal systems over the Pacific takes place. The proximity of one of the most important WCB inflow region to East Asia is an important factor (Stohl, 2001, and references therein). The WCB lifts the Asian air masses towards the North Pacific where many of the air flows observed above our site pass by. We have started to speculate on a potential impact of the rising Asian air pollution on the ozone concentrations in the upper troposphere and the lower stratosphere (UTLS). Indeed, an analysis of MOZAIC data between 1994 and 2003 has revealed a positive ozone trend in the UTLS (Thouret al al., 2006). This is confirmed by the analysis of the Hohenpeißenberg sounding record from 1966 to 2007 (Claude et al., 2008), showing a $+7.5 \%$ decade $^{-1}$ trend after 1994 that is limited to a narrow range around $14 \mathrm{~km}$. A preliminary analysis of the Zugspitze CO within ATMOFAST has yielded a slightly positive trend of $\mathrm{CO}$ in stratospheric intrusions since the beginning of the $\mathrm{CO}$ measurements in 1990, opposing the slightly negative trend for non-stratospheric conditions (ATMOFAST, 2005).

More measurements are needed to harden further the reproducibility of these observations. In particular, we plan to intensify simultaneous lidar sounding of ozone, water vapour and aerosols. Accurate side-by-side $\mathrm{H}_{2} \mathrm{O}$ measurements are needed as an important information for quantifying the tropospheric influence in these dry air streams. Our new high-power water-vapour lidar has yielded humidity profiles for the entire troposphere with just minor restrictions during daytime, as a result of an application of the differentialabsorption technique (Vogelmann and Trickl, 2008).

\section{Supplementary material related to this article is available online at: http://www.atmos-chem-phys.net/11/ 9343/2011/acp-11-9343-2011-supplement. Dateinamevonsupplement.}

Acknowledgements. The authors thank P. Fabian and W. Seiler for their interest and support. They are indebted to P. James who carried out the 15-day simulations with FLEXPART, but cannot co-author this paper for specific reasons. They thank H. Feldmann for generating plots from the one-year EURAD run for 2001, J. Keller for preparing the PSI sonde system and carefully archiving the data, H. E. Scheel for providing the local station data and H. Claude for making available data from the Hohenpeißenberg sonde archive. Furthermore, they thank the MOZAIC team for allowing them to access their data base, O. Cooper and A. Volz- 
Thomas for their help with literature, as well as R. Steinbrecher and L. G. Ruiz Suárez for providing the link to the station data for Mexico City. This work has been funded by the European Union within the VOTALP (Vertical Ozone Transport in the Alps, parts 1 and 2), STACCATO (Influence of Stratosphere-Troposphere Exchange in a Changing Climate on Atmospheric Transport and Oxidation Capacity; e.g., Stohl et al., 2003) and EARLINET (European Aerosol Research Lidar Network) projects as well as by the German Federal M inistry of Education and Research the programme "Atmosphärenforschung 2000" (ATMOFAST project: Atmospheric Long-range Transport and its Impact on the Trace-gas Composition in the Free Troposphere over Central Europe) and the German Aerosol Lidar Network.

Edited by: T. J. Dunkerton

\section{References}

AFO 2000: Results of the German Atmospheric Research Programme, edited by: Winkler, R., German Federal Ministry of Education and Research (BMBF), Publications and Website Division, Berlin, Germany, 265 pp., 2005.

ATMOFAST: Atmosphärischer Ferntransport und seine Auswirkungen auf die Spurengaskonzentrationen in der freien Troposphäre über Mitteleuropa (Atmospheric Long-range Transport and its Impact on the Trace-gas Composition of the Free Troposphere over Central Europe), Project Final Report, T. Trickl, Co-ordinator, M. Kerschgens, A. Stohl, and T. Trickl, subproject co-ordinators, funded by the German Ministry of Education and Research within the programme “Atmosphärenforschung 2000" (in German), 130 pp., available at: http://www.trickl.de/ATMOFAST.htm, 2005.

Austin, J. F. and Midgley, R. P.: The Climatology of the jet stream and stratospheric intrusions of ozone over Japan, Atmos. Environ., 28, 39-52, 1994.

Beirle, S., Spichtinger, N., Stohl, A., Cummins, K. L., Turner, T., Boccippio, D., Cooper, O. R., Wenig, M., Grzegorski, M., Platt, U., and Wagner, T.: Estimating the $\mathrm{NO}_{\mathrm{x}}$ produced by lightning from GOME and NLDN data: a case study in the Gulf of Mexico, Atmos. Chem. Phys., 6, 1075-1089, doi:10.5194/acp-6-10752006, 2006.

Bithell, M., Vaughan, G., and Gray, L. J.: Persistence of stratospheric ozone layers in the troposphere, Atmos. Environ., 34, 2563-2570, 2000.

Cammas, J.-P., Jacoby-Koaly, S., Suhre, K., Rosset, R., and Marenco, A.: Atlantic subtropical potential vorticity barrier of Ozone by Airbus In-Service Aircraft (MOZAIC) flights, J. Geophys. Res., 103, 25681-25693, 1998.

Carnuth, W., Kempfer, U., and Trickl, T.: Highlights of the Tropospheric Lidar Studies at IFU within the TOR Project, Tellus B, 54, 163-185, 2002.

Chen, P.: Isentropic cross-tropopause mass exchange in the extratropics, J. Geophys. Res., 100, 16661-16673, 1995.

Claude, H., Steinbrecht, W., and Köhler, U.: Entwarnung bei der Ozonschicht, Ozonbulletin des Deutschen Wetterdiensts, available at: http://www.dwd.de, 119, 2, 2008 (in German).

Cooper, O. R., Forster, C., Parrish, D., Trainer, M., Dunlea, E., Ryerson, T., Hübler, G., Fehsenfeld, F., Nicks, D., Holloway, J., de Gouw, J., Warneke, C., Roberts, J. M., Flocke, F., and Moody, J.:
A case study of transpacific warm conveyor belt transport: Influence of merging airstreams on trace gas import to North America, J. Geophys. Res., 109, D23S08, doi:10.1029/2003JD003624, 2004a.

Cooper, O., Forster, C., Parrish, D., Dunlea, E., Hübler, G., Fehsenfeld, F., Holloway, J., Oltmans, S., Johnson, B., Wimmers, A., and Horowitz, L.: On the life cycle of a stratospheric intrusion and its dispersion into polluted warm conveyor belts, J. Geophys. Res., 109, D23S09, doi:10.1029/2003JD00400618, 2004b.

Cooper, O. R., Stohl, A., Hübler, G., Hsie, E. Y., Parrish, D. D., Tuck, A. F., Kiladis, G. N:, Oltmans, S. J., Johnson, B. J., Shapiro, M., Moody, J. L, and Lefohn, A. S.: Direct transport of midlatitude stratospheric ozone into the lower troposphere and marine boundary layer of the tropical Pacific Ocean, J. Geophys. Res., 100, D23310, doi:10.1029/2005JD005783, 2005.

Cooper, O. R., Stohl, A., Trainer, M., Thompson, A. M., Witte, J. C., Oltmans, S. J., Morris, G., Pickering, K. E., Crawford, J. H., Chen, G., Cohen, R. C., Bertram, T. H., Wooldridge., P., Perring, A., Brune, W. H., Merrill, J., Moody, J. L., Tarasick, D., Nédélec, P., Forbes, G., Newchurch, M. J., Schmidlin, F. J., Johnson, B. J., Turquety, S., Baughcum, S. L., Ren, X., Fehsenfeld, F. C., Meagher, J. F., Spichtinger, N., Brown, C. C., McKeen, S. A., McDermid, I. S., and Leblanc, T.: Large upper tropospheric ozone enhancements above midlatitude North America during summer: In situ evidence from the IONS and MOZAIC ozone measurements network, J. Geophys. Res. 111, D24S05, doi:10.1029/2006JD007306, 2006.

Cristofanelli, P., Bonasoni, P., Collins, W., Feichter, J., Forster, C., Kentarchos, A., Kubik, P. W., James, P., Land, C., Meloen, J., Roelofs, G. J., Siegmund, P., Sprenger, M., Schnabel, C., Stohl, A., Tositti, L., Trickl, T., Wernli, H., and Zanis, P.: Stratosphere to troposphere transport: a model and method evaluation, J. Geophys. Res., 108, 8525, doi:10.1029/2002JD002600, 2003.

Danielsen, E. F.: Stratospheric-Tropospheric Exchange Based on Radioactivity, Ozone and Potential Vorticity, J. Atmos. Sci., 25, 502-518, 1968.

Davies, T. D. and Schuepbach, E.: Episodes of high ozone concentrations at the earth's surface resulting from transport down from the upper troposphere/lower stratosphere: a review and case studies, Atmos. Environ., 28, 53-68, 1994.

Deshler, T., Anderson-Sprecher, R., Jäger, H., Barnes, J., Hofmann, D. J., Clemensha, B., Simonich, D., Grainger, R. G., and GodinBeekmann, S.: Trends in the non-volcanic component of stratospheric aerosol over the period 1971-2004, J. Geophys. Res., 111, D01201, doi:10.1029/2005JD00608, 2006.

Ding, A. J., Wang, T., Thouret, V., Cammas, J.-P., and Nédélec, P.: Tropospheric ozone climatology over Beijing: analysis of aircraft data from the MOZAIC program, Atmos. Chem. Phys., 8, 1-13, doi:10.5194/acp-8-1-2008, 2008.

Draxler, R. and Hess, G.: An overview of the HYSPLIT_4 modelling system for trajectories, dispersion, and deposition, Aust. Meteorol. Mag., 47, 295-308, 1998.

Dunkerton, T. J.: Evidence of meridional motion in the summer lower stratosphere adjacent to monsoon regions, J. Geophys. Res., 100, 16675-16688, 1995.

Eisele, H. and Trickl, T.: Second Generation of the IFU Stationary Tropospheric Ozone Lidar, in: Advances in Atmospheric Remote Sensing with Lidar, Selected Papers of the 18th International Laser Radar Conference, Berlin (Germany), 22 to 26 July 1996, 
edited by: Ansmann, A., Neuber, R., Rairoux, P., and Wandinger, U., Springer, Berlin, Heidelberg, Germany, 79-382, 1997.

Eisele, H. and Trickl, T.: Improvements of the aerosol algorithm in ozone-lidar data processing by use of evolutionary strategies, Appl. Optics, 44, 2638-2651, 2005.

Eisele, H., Scheel, H. E., Sladkovic, R., and Trickl, T.: Highresolution Lidar Measurements of Stratosphere-troposphere Exchange, J. Atmos. Sci., 56, 319-330, 1999.

Elbern, H., Kowol, J., Sladkovic, R., and Ebel, A.: Deep stratospheric intrusions: A statistical assessment with model guided analysis, Atmos. Environ., 31, 3207-3226, 1997.

Emanuel, K. A. and Živković-Rothman, M.: Development and evaluation of a convection scheme for use in climate models, J. Atmos. Sci., 56, 1766-1782, 1999.

Fehsenfeld, F. C., Ancellet, G., Bates, T. S., Goldstein, A. H., Hardesty, R. M., Honrath, R., Law, K. S., Lewis, A. C., Leaitch, R., McKeen, S., Meagher, J., Parrish, D. D., Pszenny, A. A. P., Russell, P. B., Schlager, H., Seinfeld, J., Talbot, R., and Zbinden, R.: International consortium for atmospheric research on transport and transformation (ICARTT): North America to Europe Overview of the 2004 summer field study, J. Geophys. Res., 111, D23S01, doi:10.1029/2006JD007829, 2006.

Feldmann, H., Memmesheimer, M., Ebel, A., Seibert, P., Wotawa, G., Kromp-Kolb, H., Trickl, T., and Prévôt, A.: Evaluation of a Regional Scale Model for the Alpine Region with Data from the VOTALP Project, in: Proceedings of EUROTRAC Symposium 1998, Garmisch-Partenkirchen (Germany), March 23-17, 1998, edited by: Borrell, P. M. and Borrell, P., WITpress, Southampton, UK, 483-488, 1999.

Folkins, I. and Appenzeller, C.: Ozone and potential vorticity at the subtropical tropopause break, J. Geophys. Res., 101, 1878718792, 1996.

Forster, C., Wandinger, U., Wotawa, G., James, P., Mattis, I., Althausen, D., Simmonds, P., O'Doherty, S., Jennings, S. G., Kleefeld, C., Schneider, J., Trickl, T., Kreipl, S., Jäger, H., and Stohl, A.: Transport of boreal forest fire emissions from Canada to Europe, J. Geophys. Res., 106, 22887-22906, 2001.

Forster, C., Stohl, A., and Seibert, P.: Parameterization of convective transport in a Lagrangian particle dispersion model and its valuation, J. Appl. Meteor. Clim., 46, 403-422, 2007.

Freudenthaler, V., Homburg, F., and Jäger, H.: Ground-based mobile scanning LIDAR for remote sensing of contrails, Ann. Geophys., 12, 956-961, doi:10.1007/s00585-994-0956-9, 1994.

Freudenthaler, V., Homburg, F., and Jäger, H.: Contrail observations by ground-based mobile scanning lidar: cross-sectional growth, Geophys. Res. Lett., 22, 3501-3504, 1995.

Fromm, M., Shettle, E. P., Fricke, K. H., Ritter, C., Trickl, T., Giehl, H., Gerding, M., Barnes, J., O’Neill, M., Massie, S. T., Blum, U., McDermid, I. S., Leblanc, T., and Deshler, T.: The stratospheric impact of the Chisholm PyroCumulonimbus eruption: 2. Vertical profile perspective, J. Geophys. Res., 113, D08203, doi:10.1029/2007JD009147, 2008.

Fromm, M., Lindsey, D. T., Servranckx, R., Yue, G., Trickl, T., Sica, R., Doucet, P., and Godin-Beekmann, S.: The Untold Story of Pyrocumulonimbus, Bull. Am. Meterol. Soc., 91, 1193-1209, 2010.

Frost, G. J., McKeen, S. A., Trainer, M., Ryerson, T. B., Neuman, J. A., Roberts, J. M., Swanson, A., Holloway, J. S., Sueper, D. T., Parrish, D. D., Fehsenfeld, F. C., Flocke, F., Peckham, S. E.,
Grell, G. A., Kowal, D., Cartwright, J., Auerbach, N., and Habermann, T.: Effects of changing power plant $\mathrm{NO}_{\mathrm{x}}$ emissions on ozone in the eastern United States: Proof of concept, J. Geophys. Res., 111, D12306, doi:10.1029/2005JD006354, 2006.

Gouget, H., Cammas, J.-P., Marenco, A., Rosset, R., and Jonquières, I.: Ozone peaks associated with a subtropical tropopause fold and with the trade wind inversion: A case study from the airborne campaign TROPOZ II over the Caribbean in winter, J. Geophys. Res., 101, 25979-25993, 1996.

Grousset, F. E., Ginoux, P., Bory, A., and Biscaye, P. E.: Case study of a Chinese dust plume reaching the French Alps, Geophys. Res. Lett., 30, 1277, doi:10.1029/2002GL016833, 2003.

Huntrieser, H., Heland, J., Schlager, H., Forster, C., Stohl, A., Aufmhoff, H., Arnold, F., Scheel, H. E., Campana, M., Gilge, S., Eixmann, R., and Cooper, O.: Intercontinental air pollution transport from North America to Europe: Experimental evidence from aircraft measurements and surface observations, J. Geophys. Res., 110, DO1305, doi:10.1029/2004JD005045, 2005.

Huntrieser, H., Schlager, H., Roiger, A., Lichtenstern, M., Schumann, U., Kurz, C., Brunner, D., Schwierz, C., Richter, A., and Stohl, A.: Lightning-produced $\mathrm{NO}_{\mathrm{x}}$ over Brazil during TROCCINOX: airborne measurements in tropical and subtropical thunderstorms and the importance of mesoscale convective systems, Atmos. Chem. Phys., 7, 2987-3013, doi:10.5194/acp-7-29872007, 2007.

Jäger, H.: Long-term record of lidar observations of the stratospheric aerosol layer at Garmisch-Partenkirchen, J. Geophys. Res., 110, D08106, doi:10.1029/2004JD005506, 2005.

Jäger, H., Carnuth, W., and Georgi, B.: Observations of Saharan Dust at a North Alpine Station, J. Aerosol Sci., 19, 1235-1238, 1988

Jäger, H., James, P., Stohl, A., and Trickl, T: Long-Range Transport of Free-Tropospheric Aerosol: A Nine-year Climatology, in: Reviewed and Revised Papers Presented at the 23rd International Laser Radar Conference, Nara (Japan), 24 to 28 July 2006, edited by: Nagasawa, C. and Sugimoto, N., Tokyo Metropolitan University, Tokyo, Japan, ISBN 4-9902916-0-3795-796, 2006.

James, P., Stohl, A., Forster, C., Eckhardt, S., Seibert, P., and Frank, A.: A 15-year climatology of stratosphere-troposphere exchange with a Lagrangian particle dispersion model, 2. Mean climate and seasonal variability, J. Geophys. Res., 108, 8522, doi:10.1029/2002JD002639, 2003.

Kempfer, U., Carnuth, W., Lotz, R., and Trickl, T.: A wide-range UV lidar system for tropospheric ozone measurements: development and application, Rev. Sci. Instrum., 65, 3145-3164, 1994.

Keyser, D. and Shapiro, M. A.: A Review of the Structure and Dynamics of Upper-Level Frontal Zones, Mon. Weather Rev. 114, 452-499, 1986.

Koch, P., Wernli, H., and Davies, H. C.: An Event-based Jet-stream Climatology and Typology, Int. J. Climatol., 26, 283-301, 2006.

Kreipl, S., Mücke, R., Jäger, H., Trickl, T., and Stohl, A.: Spectacular Cases of Vertical and Long-range Ozone and Aerosol Transport, in: Laser Remote Sensing of the Atmosphere, Selected Papers of the 20th International Laser Radar Conference, Vichy (France), 10 to 14 July 2000, edited by: Dabas, A. and Pelon, J., Éditions de l'École Polytechnique, Paris, France, 455-458, 2001.

Krishnamurti, T. N.: The Subtropical Jet Stream of Winter, J. Meteor., 18, 172-191, 1961. 
Kritz, M. A., Le Roulley, J.-C., and Danielsen, E. F.: The China Clipper - fast advective transport of radon-rich air from the Asian boundary layer to the upper troposphere near California, Tellus B, 42, 46-61, 1990.

Langford, A. O.: Stratosphere-troposphere exchange at the subtropical jet, contribution to the tropospheric ozone budget at midlatitudes, Geophys. Res. Lett, 26, 2449-2452, 1999.

Langford, A. O., OLeary, T. J., Masters, C. D., Aikin, K. C., and Proffitt, M. H.: Modulation of middle and upper tropospheric ozone at Northern midlatitudes by the El Niño/Southern Oscillation, Geophys. Res. Lett., 25, 2667-2670, 1998.

Law, K. S., Penkett, S. A., Reeves, C. E., Evans, M. J., Pyle, J. A., Bauguitte, S., Green, T. J., Bandy, B., Mills, G. P., Barjat, H., Kley, D., Schmitgen, S., Monks, P. S., Edwards, G. D., Kent J. M., Dewey, K., and Kaye, A.: Evidence for anthropogenic influence over the central North Atlantic. IGACtivities, International Global Atmospheric Chemistry, Newsletter 24, $17-$ 19, 2001.

Liang, Q., Jaeglé, L., Hudman, R. C., Turquety, S., Jacob, D. J., Avery, M. A., Browell, E. V., Sachse, G. W., Blake, D. R., Brune, W., Ren, X., Cohen, R. C., Dibb, J. E., Fried, A., Fuelberg, H., Porter, M., Heikes, B. G., Huey, G., Singh, H. B., and Wennberg, P. O.: Summertime influence of Asian pollution in the free troposphere over North America, J. Geophys. Res., 112, D12S11, doi:10.1029/2006JD007919, 2007.

Ma, J. and van Aardenne, J. A.: Impact of different emission inventories on simulated tropospheric ozone over China: a regional chemical transport model evaluation, Atmos. Chem. Phys., 4, 877-887, doi:10.5194/acp-4-877-2004, 2004.

Marenco, A., Thouret, V., Nédélec, P., Smit, H., Helten, M., Kley, D., Karcher, F., Simon, P., Law, K., Pyle, J., Poschmann, G., von Wrede, R., Hume, C., and Cook, T.: Measurement of ozone and water vapor by Airbus in-service aircraft: The MOZAIC airborne program, An overview, J. Geophys. Res., 103, 25631-25642, 1998.

Meloen, J., Siegmund, P., van Velthoven, P., Kelder, H., Sprenger, M., Wernli, H., Kentarchos, A., Roelofs, G., Feichter, J., Land, C., Forster, C., James, P., Stohl, A., Collins, B., and Cristofanelli, P.: Stratosphere troposphere exchange: a model and method intercomparison, J. Geophys. Res., 108, 8526, doi:10.1029/2002JD002274, 2003.

Newell, R. E., Thouret, V., Cho, J. Y. N., Stoller, P., Marenco, A., and Smit, H. G.: Ubiquity of quasi-horizontal layers in the troposphere, Nature, 198, 316-319, 1999.

Olivier, J. G. J. and Berdowski, J. J. M.: Global emissions sources and sinks, in: The Climate System, edited by: Berdowski, J., Guicherit, R., and Heij, B. J., A. A. Balkema Publishers/Swets \& Zeitlinger Publishers, Lisse, The Netherlands, ISBN 905809255 0, 33-78, 2001.

Papayannis, A., Amiridis, V., Mona, L., Tsaknakis, G., Balis, D., Bösenberg, J., Chaikovski, A., De Tomasi, F., Grigorov, I., Mattis, I., Mitev, V., Müller, D., Nickovic, S., Pérez, C., Pietruczuk, A., Pisani, G., Ravetta, F., Rizi, V., Sicard, M., Trickl, T., Wiegner, M., Gerding, M., Mamouri, R. E., D’Amico, G., and Pappalardo, G.: Systematic lidar observations of Saharan dust over Europe in the frame of EARLINET (2000-2002), J. Geophys. Res., 113, D10204; doi:10.1029/2007JD009028, 2008.

Penkett, S. A., Evans, M. J., Reeves, C. E., Law, K. S., Monks, P. S., Bauguitte, S. J. B., Pyle, J. A., Green, T. J., Bandy, B.
J., Mills, G., Cardenas, L. M., Barjat, H., Kley, D., Schmitgen, S., Kent, J. M., Dewey, K., and Methven, J.: Long-range transport of ozone and related pollutants over the North Atlantic in spring and summer, Atmos. Chem. Phys. Discuss., 4, 44074454, doi:10.5194/acpd-4-4407-2004, 2004.

Prados, A. I., Dickerson, R. R., Doddrige, B. G., Milne, P. A., Moody, J. L., and Merrill J. T.: Transport of ozone and pollutants to the North Atlantic Ocean during the 1996 Atmosphere/Ocean Chemistry Experiment (AEROCE) intensive, J. Geophys. Res., 104, 26219-26233, 1999.

Reiter, R., Sladkovic, R., Pötzl, K., Carnuth, W., and Kanter, H.J.: Studies of the influx of stratospheric air into the lower troposphere using cosmic-ray-produced radionuclides and fallout, Arch. Meteor. Geophy. A, 20A, 211-246, 1971.

Reiter, R., Sladkovic, R., and Kanter, H.-J.: Concentration of trace gases in the lower troposphere, simultaneously recorded at neighboring mountain stations, Part II: ozone, Meteorol. Atmos. Phys., 37, 27-47, 1987.

Richter, A., Burrows, J. P., Nüß, H., Granier, C., and Niemeier, U.: Increase in tropospheric nitrogen dioxide over China oberved from Space, Nature, 437, 129-132, 2005.

Roelofs, G. J., Kentarchos, A. S., Trickl, T., Stohl, A., Collins, W. J., Crowther, R. A., Hauglustaine, D., Klonecki, A., Law, K. S., Lawrence, M. G., von Kuhlmann, R., and van Weele, M.: Intercomparison of tropospheric ozone models: Ozone transport in a complex tropopause folding event, J. Geophys. Res., 108, 8529, doi:10.1029/2003JD003462, 2003.

Schuepbach, E., Davies, T. D., Massacand, A. C., and Wernli, H.: Mesoscale modelling of vertical atmospheric transport in the Alps associated with the advection of a tropopause fold - a winter ozone episode, Atmos. Environ., 33, 3613-3626, 1999.

Schumann, U. and Huntrieser, H.: The global lightning-induced nitrogen oxides source, Atmos. Chem. Phys., 7, 3823-3907, doi:10.5194/acp-7-3823-2007, 2007.

Seibert, P. and Frank, A.: Source-receptor matrix calculation with a Lagrangian particle dispersion model in backward mode, Atmos. Chem. Phys., 4, 51-63, doi:10.5194/acp-4-51-2004, 2004.

Seibert, P., Feldmann, H., Neininger, B., Bäumle, M., and Trickl, T.: South foehn and ozone in the Eastern Alps - case study and climatological aspect, Atmos. Environ., 34, 1379-1394, 2000.

Singh, H. B., Salas, L., Herlth, D., Kolyer, R., Czech, E., Avery, M., Crawford, J. H., Pierce, R. B., Sachse, G. W., Blake, D. R., Cohen, R. C., Bertram, T. H., Perring, A., Wooldridge, P. J., Dibb, J., Huey, G., Hudman, R. C., Turquety, S., Emmons, L. K., Flocke, F., Tang, Y., Carmichael, G. R., and Horowitz, L. W.: Reactive nitrogen distribution and partitioning in the North American troposphere and lowermost stratosphere, J. Geophys. Res. 112, D12S04, doi:10.1029/2006JD007664, 2007.

Sioris, C. E., McLinden, C. A., Martin, R. V., Sauvage, B., Haley, C. S., Lloyd, N. D., Llewellyn, E. J., Bernath, P. F., Boone, C. D., Brohede, S., and McElroy, C. T.: Vertical profiles of lightning-produced $\mathrm{NO}_{2}$ enhancements in the upper troposphere observed by OSIRIS, Atmos. Chem. Phys., 7, 42814294, doi:10.5194/acp-7-4281-2007, 2007.

Sprenger, M. and Wernli, H.: A northern hemisphere climatology of cross-tropopause exchange for the ERA 15 time period, J. Geophys. Res., 108, 8521, doi:10.1029/2002JD002636, 2003.

Sprenger, M., Croci Maspoli, M., and Wernli, H.: Tropopause folds and cross-tropopause exchange: A global investiga- 
tion based upon ECMWF analyses for the time period March 2000 to February 2001, J. Geophys. Res., 108, 8518, doi:10.1029/2002JD002587, 2003.

Stohl, A.: A 1-year Lagrangian "climatology" of airstreams in the Northern Hemisphere troposphere and lowermost stratosphere, J. Geophys. Res., 106, 7263-7279, 2001.

Stohl, A. and Seibert, P.: Accuracy of trajectories as determined from the conservation of meteorological tracers, Q. J. Roy. Meteor. Soc., 124, 1465-1484, 1998.

Stohl, A. and Thomson, D. J.: A density correction for Lagrangian particle dispersion models, Bound.-Lay. Meteorol., 90, 155-167, 1999.

Stohl, A. and Trickl, T.: A textbook example of long-range transport: Simultaneous observation of ozone maxima of stratospheric and North American origin in the free troposphere over Europe, J. Geophys. Res., 104, 30445-30462, 1999.

Stohl, A., Wotawa, G., Seibert, P., and Kromp-Kolb, H.: Interpolation errors in wind fields as a function of spatial and temporal resolution and their impact on different types of kinematic trajectories, J. Appl. Meteorol., 34, 2149-2165, 1995.

Stohl, A., Hittenberger, M., and Wotawa, G.: Validation of the Lagrangian particle dispersion model FLEXPART against large scale tracer experiments, Atmos. Environ., 32, 4245-4264, 1998.

Stohl, A., Spichtinger-Rakowsky, N., Bonasoni, P., Feldmann, H., Memmesheimer, M., Scheel, H. E., Trickl, T., Hübener, S., Ringer, W., and Mandl, M.: The influence of stratospheric intrusions on alpine ozone concentrations, Atmos. Environ., 34, 1323-1354, 2000.

Stohl, A., Eckhardt, S., Forster, C., James, P., Spichtinger, N., and Seibert, P.: A replacement for simple back trajectory calculations in the interpretation of atmospheric trace substance measurements, Atmos. Environ., 36, 4635-4648, 2002.

Stohl, A., Eckhardt, S., Spichtinger, N., Huntrieser, H., Heland, J., Schlager, H., Wilhelm, S., Arnold, F., and Cooper, O.: A backward modelling study of intercontinental transport using aircraft measurements, J. Geophys. Res., 108, 4370, doi:10.1029/2002JD002862, 2003.

Stohl, A., Bonasoni, P., Cristofanelli, P., Collins, W., Feichter, J., Frank, A., Forster, C., Gerasopoulos, E., Gggeler, H., James, P., Kentarchos, T., Kromp-Kolb, H., Krüger, B., Land, C., Meloen, J., Papayannis, A., Priller, A., Seibert, P., Sprenger, M., Roelofs, G. J., Scheel, H. E., Schnabel, C., Siegmund, P., Tobler, L., Trickl, T., Wernli, H., Wirth, V., Zanis, P., and Zerefos, C.: Stratosphere-troposphere exchange - a review, and what we have learned from STACCATO, J. Geophys. Res., 108, 8516, doi:10.1029/2002JD002490, 2003.

Stohl, A., Forster, C., Frank, A., Seibert, P., and Wotawa, G.: Technical note: The Lagrangian particle dispersion model FLEXPART version 6.2, Atmos. Chem. Phys., 5, 2461-2474, doi:10.5194/acp-5-2461-2005, 2005.

Stohl, A., Forster, C., Huntrieser, H., Mannstein, H., McMillan, W. W., Petzold, A., Schlager, H., and Weinzierl, B.: Aircraft measurements over Europe of an air pollution plume from Southeast Asia - aerosol and chemical characterization, Atmos. Chem. Phys., 7, 913-937, doi:10.5194/acp-7-913-2007, 2007.
Thouret, V., Cammas, J.-P., Sauvage, B., Athier, G., Zbinden, R., Nédélec, P., Simon, P., and Karcher, F.: Tropopause referenced ozone climatology and inter-annual variability (1994-2003) from the MOZAIC programme, Atmos. Chem. Phys., 6, 1033-1051, doi:10.5194/acp-6-1033-2006, 2006.

Trickl, T., Cooper, O. C., Eisele, H., James, P., Mücke, R., and Stohl, A.: Intercontinental transport and its influence on the ozone concentrations over central Europe: Three case studies, J. Geophys. Res., 108, 8530, doi:10.1029/2002JD002735, 2003.

Trickl, T., Bärtsch-Ritter, N., Eisele, H., Furger, M., Mücke, R., and Stohl, A.: High-ozone layers in the middle and upper troposphere above Central Europe: strong import from the stratosphere over the Pacific Ocean, Atmos. Chem. Phys. Discuss., 9, 3113-3166, doi:10.5194/acpd-9-3113-2009, 2009.

Trickl, T., Feldmann, H., Kanter, H.-J., Scheel, H.-E., Sprenger, M., Stohl, A., and Wernli, H.: Forecasted deep stratospheric intrusions over Central Europe: case studies and climatologies, Atmos. Chem. Phys., 10, 499-524, doi:10.5194/acp-10-499-2010, 2010.

Vogelmann, H. and Trickl, T.: Wide-range sounding of freetropospheric water vapor with a differential-absorption lidar (DIAL) at a high-altitude station, Appl. Optics, 47, 2116-2132, 2008.

VOTALP II: Vertical Ozone Transport in the Alps II, Final Report for the European Union, Contract Nr.: ENV4 CT970413, Reporting Period 1/3/1998-29/2/2000, H. Kromp-Kolb, Co-ordinator, Universität für Bodenkultur Wien (Austria), Institut für Meteorologie und Physik, available at: http://www.boku.ac.at/imp/ votalp/, 96 pp., 2000.

Wernli, H. and Davies, H. C.: A Lagrangian-based analysis of extratropical cyclones. I. The method and some applications, Q. J. Roy. Meteorol. Soc., 123, 467-489, 1997a.

Wernli, H. and Davies, H. C.: A Lagrangian-based analysis of extratropical cyclones. II: A detailed case study, Q. J. Roy. Meteorol. Soc., 123, 1677-1706, 1997b.

Wernli, H. and Bourqui, M.: A Lagrangian ,"one-year climatology" of (deep) cross-tropopause in the extratropical northern hemisphere, J. Geophys. Res., 107, 4021, doi:10.1029/2001JD000812, 2002.

Zachariasse, M., van Velthoven, P. F. J., Smit, H. G. J., Lelieveld, J., Mandal, T. K., and Kelder, H.: Influence of stratospheretroposphere exchange over the tropical Indian Ocean during the winter monsoon, J. Geophys. Res., 105, 15403-15416, 2000.

Zahn, A., Brenninkmeyer, C. A. M., Asman, W. A. H., Crutzen, P. J., Heinrich, G., Fischer, H., Cuijpers, J. W. M., and van Velthoven, P. F. J.: Budgets of $\mathrm{O}_{3}$ and $\mathrm{CO}$ in the upper troposphere: CARIBIC passenger aircraft results 1997-2001, J. Geophys. Res., 107, 4337, doi:10.1029/2001JD001529, 2002.

Zanis, P., Trickl, T., Stohl, A., Wernli, H., Cooper, O., Zerefos, C., Gaeggeler, H., Schnabel, C., Tobler, L., Kubik, P. W., Priller, A., Scheel, H. E., Kanter, H. J., Cristofanelli, P., Forster, C., James, P., Gerasopoulos, E., Delcloo, A., Papayannis, A., and Claude, H.: Forecast, observation and modelling of a deep stratospheric intrusion event over Europe, Atmos. Chem. Phys., 3, 763-777, doi:10.5194/acp-3-763-2003, 2003. 